
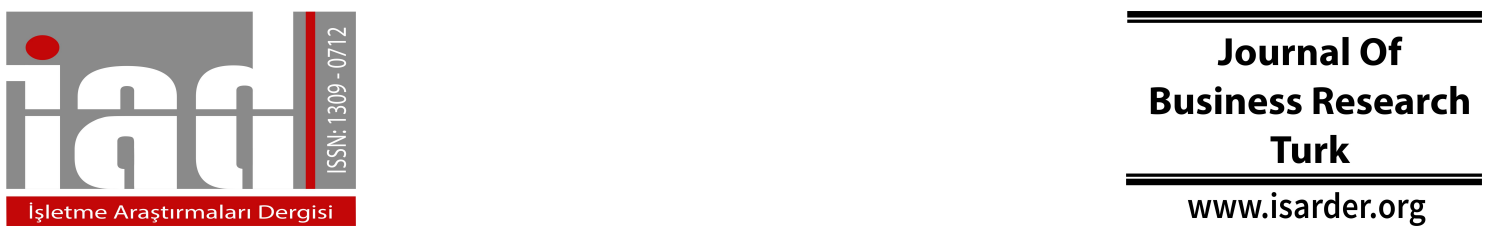

\title{
Performance Analysis Of Banks In Turkey Using Camels Approach Case Study: Six Turkish Banks During 2005 To 2016
}

\author{
Masoud Ghazavi* \\ Financial Specialist \\ Bank Mellat, Tehran, Iran \\ orcid.org/0000-0002-3973-1076 \\ Ghaz1370@yahoo.com
}

\author{
Sema Bayraktar \\ İstanbul Bilgi University \\ School of Applied Sciences \\ İstanbul, Turkey \\ orcid.org/0000-0002-7564-4148 \\ sema.bayraktar@bilgi.edu.tr
}

\begin{abstract}
This study analyzes the performance and financial credibility of six Turkish banks for the period of 2005-2016. The sample comprises two state-owned deposit banks, three private-owned deposit banks, and one foreign bank. As one of the most popular methods for measuring banking performance, CAMELS method is used to analyze the performance of the banks. CAMELS stands for Capital Adequacy, Asset Quality, Management Efficiency, Earning Quality, Liquidity, Sensitivity respectively. When the average rates of 2014, 2015 and 2016 ratios -for each one of these mentioned categories- separately examined, none of the banks is found to be superior to the others. As for the composite rate for CAMELS though, Ziraat Bank has the highest rate $(29.32 \%)$ and Halkbank stands at the last row (21.94\%). Overall, the values of the CAMELS ratios for 2016 seem to be quite close to each other. However, when the yearly analysis is conducted, some significant differences in the categories of CAMELS ratio are observed. In addition, ANOVA test results state that the means of CAMELS ratios are significantly different over the years. Finally, comparison of CAMELS ratings with institutional ratings shows that the latter does lag the financial indicators of the companies and even can be not reflective of the current financial condition of the company. On the other hand, the trends of the institutional ratings and of financial indicators are consistent over a long period of time.
\end{abstract}

Keywords: Banking, Performance Analysis, CAMELS Approach, ANOVA Test, International Rating Agencies 


\section{INTRODUCTION}

Banks, in today's world, play a very important role in maintaining the stability of different sectors of the economy. Apart from the main function of just being an institution to safeguard people's deposit, it acts as an intermediary to purvey loans to the economy and provide diverse services for businesses. Therefore, the health and soundness of banks are very crucial to ensure smooth and robust economic development of any country.

World financial organizations such as Bank for International Settlement (BIS), have tried to codify some supervisory regulations for such an important sector. Three sets of these collections are known as Basel I, Basel II and Basel III guidelines. Basel I was announced in 1988, in which two key issues were emphasized. The first one was related to capital adequacy ratio for the banks and the other was related to the classification of their assets. These rules were implemented in the early 1990s in main banks. Since in the course of time it appeared that Basel I had some deficiencies, Basel II was launched which included methods of hedging different risks. According to Basel II, internal supervision of banks was more emphasized. With the recommendations of Basel II, rating agencies also came to the fore and took a considerable role to play in the financial industry. Subsequently, the emergence of 2008 global crisis proved that the prudential rules devised by Basel committee need to be revised and reinforced. Based on this revision, more emphasis has been given to the specific risks related to individual banks and also the weights assigned to different categories of the assets went under serious amendments.

Just in order to have a summarized picture of Turkish banking system, it is worth mentioning that as of September 2017, there are a total of 46 banks operating in Turkey and the total assets of Turkish banking sector is USD 737 billion. (www.tbb.org.tr). Distribution of total assets among each group as of September 2017 is illustrated in percentages in Figure1. Privately owned commercial banks have a portion of $37 \%$ of the total assets in Turkish banking system. On the other hand, State-owned commercial banks, Foreign banks, Development and Investment banks have portions of 31\%, 26\%, and $6 \%$, respectively. 


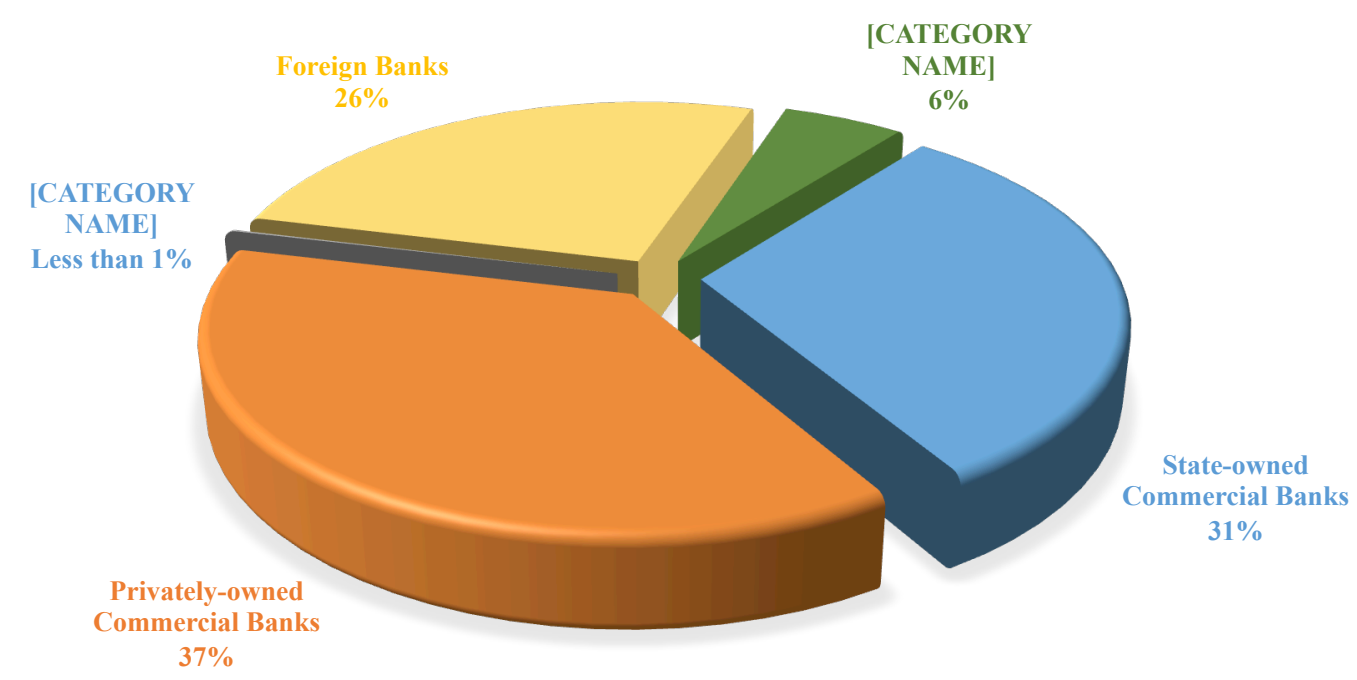

Figure 1.Distribution of Total Assets by Group (\%)

We have presented a rating system with a numeric range from 0 to 100 by using all components of CAMELS ratios. The categories used in the evaluation process are illustrated in Figure 2; Capital Adequacy, Asset Quality, Management Efficiency, Earning Quality, Liquidity, Sensitivity, namely.

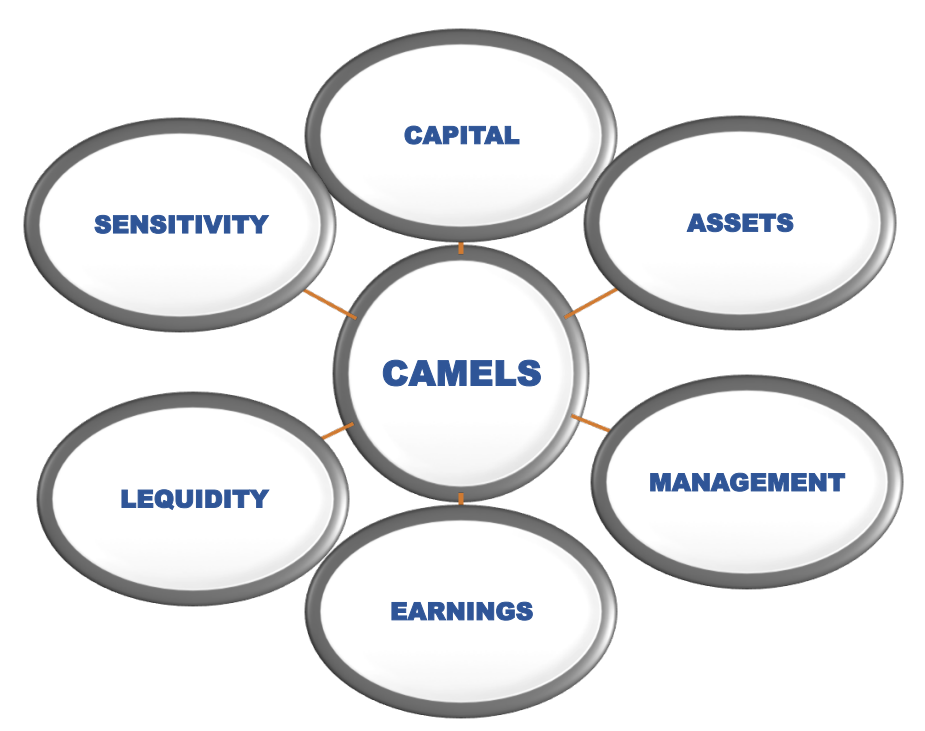

Figure 2. CAMELS Categories

\section{LITERATURE}

Since the 1970s, CAMEL rating system has been one of the widely used performance measurement techniques used by the supervisory authorities. In 1979, the Uniform Financial Institutions Rating System (UFIRS) was adopted by US banking institutions (Siems \& Barr, 1998). This rating system later became known as CAMEL, 
reflecting five different evaluation areas: capital, asset quality, management, earnings and liquidity ratios (Cox \& Cox, 2006). Supervisory authorities considering the changing risks of the markets have added another evaluation criteria reflecting the management of market risk which replaced CAMEL with CAMELS (Broz, 1997). In 1988, Basel Committee on Banking Supervision of the Bank of International Settlements (BIS) suggested the CAMELS rating system to be used for evaluation of financial institutions (Dash \& Das, 2009). Many studies have used CAMELS rating system to analyze the performance of financial institutions and found the system quite useful in terms of judging their financial conditions. For example, Barr et al. (2002) argued that "CAMEL rating has become a necessary evaluating instrument for regulators".

One study by Rebel Cole and Jeffery Gunther (1995) use CAMEL ratings to assess the performance of the banks and compare it with an off- site monitoring system based on financial data which is usually available for the public. According to their findings, if a bank is not verified for more than two seasons, therefore, off-site monitoring normally results in a more credible assessment. Another study by Nabilah Rozzani and Rashidah Abdul Rahman (2013) tries to compare the performance of Islamic banks with Conventional ones. They chose 19 conventional banks and 16 Islamic banks from 2008 to 2011. They conclude that among the main categories of CAMELS rating, Management Quality (1.00) received the best rating. Asset Quality (1.91) stood second in order, Shariah Compliance got 2.05, Capital Adequacy had a rating of 2.10, Earnings Quality and Liquidity were in the rest of the row respectively. Ishaq AB et al (2016) also, by choosing ten commercial banks in Pakistan for 20072013, have tried to verify the banks' performance based on CAMELS rating.

Although there are many types of research that have used CAMELS analysis method in analyzing the banks' performance worldwide, the number of studies that focus on Turkish banking sector, an emerging country, is restricted. For example, Yasemin T. Kaya (2001) has done a CAMELS analysis for Turkish banks from 1997 to 2000. This paper results have shown that all the components of CAMELS have been deteriorated in 2000 compared to 1997. G. Arıçelik (2010) demonstrated CAMELS analysis for 13 Turkish banks from 2002 to 2009. From 2002 to 2007, CAMELS performance shows a stable situation. In 2007, Akbank had the highest score of 32.61 while Yapı Kredi Bank had the lowest score (-45.79). In the second term of this study, from 2008 to 2009, which was global crisis period, Akbank had the highest score.

Ali Şen and Süleyman Solak (2011) also evaluate Turkish commercial banking sector using CAMELS ratios. They intend to verify if the CAMELS model is able to predict banking crisis. They cover some public, private and foreign commercial banks for the period of 1995-2008. They concluded that after 2001 crisis commercial banks performance improved considerably while the performance of public banks has been better. They finally concluded that CAMELS approach is capable to analyze the performance of the banks.

G. Öztorul (2011) analyzed top 14 Turkish banks during the year 2006 to 2010. She has used Data Envelopment Analysis (DEA) approach and CAMELS analysis. According to the results, if the public assets and liabilities are excluded, efficiency levels of state banks fall. CAMELS results show that the state banks and the domestic private banks have high CAMELS ratios. 
H. Dinçer et al. (2011) depicted the performance evaluation of Turkish banks after the global crisis by using CAMELS ratios for the period 2002 to 2009 . The equity ratio for the banks was higher than $8 \%$. In terms of performance evaluation some positive development was seen for of State-owned, Privately-owned and Foreign Banks after the crisis of 2001 and 2008 crisis. Especially after 2001 crisis, different prudential rules and policy reforms were taken into force such as amendments of the banking law, rules related to capital adequacy ratio and effective internal control.

Another study done by Saeid Jalili (2014) makes a comparison between the performance of banking system in Turkey and Brazil based on CAMEL rating for the period from 2007 to 2011. The sample consisted of thirteen banks from each country. He concludes that banks in both countries are facing cost management problems. The study by M.Altan et al. (2014) compares the performance of banks in Turkey using CAMEL approach between some state-owned and private banks for the period of 20052012. It covers 15 banks. He concludes that in terms of capital adequacy component, Adabank stands the highest. In terms of asset quality, Ziraat Bank has the highest rank. As for management quality, Akbank was the highest. Halkbank occupies the highest for earning quality and finally as for liquidity, Ziraat Bank stood at the top. CAMEL method results suggest that Ziraat Bank is altogether the first among the sample banks, then Akbank, Vakif Bank, İşbank and Garanti Bank are the other efficient banks that follow.

Aydin Karapinar and Ismail Cagri Dogan (2015) analyzed the performance of Turkey's participation banks and commercial banks operating in Turkey between 2006 and 2011. In order to compare the performance of the two different types of banks namely participation and conventional ones, the CAMELS approach has been used. They showed that, compared to the conventional banks, the participation banks performed better in terms of their sensitivity to the market risks, while they were poorer in terms of liquidity and management.

S. Yüksel et al. (2015) explained the relationship between CAMELS ratios and credit ratings of deposit banks in Turkey during 2004-2014. They have done their analysis by using 20 deposit banks and 21 different CAMELS ratios. They ran regression analysis and concluded that Turkish deposit bank should focus on the percentage of fixed assets and interest income to have better ratings.

This study also focuses on Turkey as an emerging country. Similar to previous studies, we also compare the banks in the sample by concentrating on a recent threeyear period, 2014-16. However, we also look at the long-term trend of the CAMELS ratio and try to see what happened to these banks during the last decade. The results show that when we look at the categories separately, none of the banks is superior to the other. Although the values of the ratios are close to each other, ANOVA test shows that there is a significant difference in the performance of the banks both for the last three years and for a longer period of 12 years. Long-term analysis also shows that performance of the analyzed banks has deteriorated over the last decade. Next section explains the methodology of the study. The results are presented in the following fourth section. The final section summarizes the conclusions. 


\section{METHODOLOGY}

The popular method called CAMELS have been used to analyze and compare the performances of the banks in the sample. To compute CAMELS ratio, 27 ratios divided into 6 categories have been used. Each ratio has a weight in its own category. Each specific ratio has been multiplied by its own weight and as a result, they have been summed up to give one for each category. As a result of calculations, there are 6 numbers for 6 categories. Later, these 6 numbers have been multiplied by their own assigned weights to give one number for the bank. This number has been computed for 12 years $(2005-2016)$.

All the categories and their components have been explained in detail in following pages of this study.

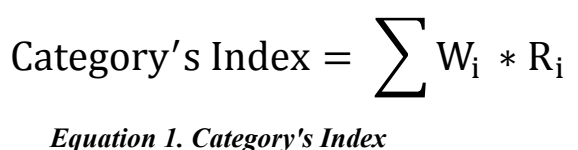

$\mathrm{W}_{\mathrm{i}}=$ Weight of each ratio and $\mathrm{R}_{\mathrm{i}}=$ Ratio

In this study for computing CAMELS rating as a tool for measuring the performance of banking sector, 27 ratios have been used. There is a relationship between each ratio and CAMELS rating. The ratio can increase or decrease the CAMELS rating based on positive $(+)$ or negative $(-)$ relation depending on its effect on the general rating of the bank. For instance, if Non-Performing Loans (NPLs) goes up, it is an undesired event and should be expected to affect negatively the bank's stability. Hence the relationship between the level of NPLs and the global rating of the related bank is negative. In contrast, the relationship between CAR and global rating of the related bank is positive since the higher the level of CAR is, the better the situation of the related bank will be.

Elements of CAMELS rating have specific weights which show their impact on the performance of the bank, for example, $\mathrm{C}$ which stands for Capital adequacy and $\mathrm{A}$ which stands for Asset quality both have been weighted as $20 \%$ and etc. These weights are based on the discretion of the experts.

Furthermore, every individual category of CAMELS ratios has got its own weight yet again upon the discretionary approach. For instance, in the category of Capital Adequacy, a weight of $20 \%$ has been assigned to the ratio of Equity to Total Liabilities. In some cases, some categories may have overlap. In a sense that one ratio may be suitable to contribute to the measurement of two different categories. In other words, the same indicator may be useable for more than one category and it may affect more than one component of CAMELS rating. "NPLs to Gross Loans" ratio affects both Asset Quality and Management Performance. However, we may consider it under one category which deems to us more prioritized, the one which is most affected. Criteria used in the selection of reference indicators are understandable, successful in measuring performance, used by banking authorities and close to standardization in the sector. The following sections explain every individual category and its related ratios. 


\subsection{Capital Adequacy}

Capital adequacy ratios as one of the six categories of CAMELS model is a measure of the amount of a bank's capital expressed as a percentage of its risk-weighted assets. Capital Adequacy is a prominent indicator of the financial soundness. Satisfactory CAR prevents the bank from bankruptcy. It also reflects whether or not a bank has sufficient capital to bear unexpected losses arising in the future and based on a certain amount of leverage. As far as Capital Adequacy category is concerned, four ratios have been taken into consideration. The Table 4 illustrates these four ratios together with their assigned weights and their positive or negative impact on the category and also on the global rating of the related bank.

Table 1. Capital Adequacy Category Ratios

\begin{tabular}{|l|l|l|}
\hline \multicolumn{3}{|c|}{ CAPITAL } \\
\hline Variables(\%) & Weight & Relationship \\
\hline CAPITAL & 0,20 & \\
\hline Capital Adequacy Ratio & 0,40 & + \\
\hline Equity / Total Liabilities & 0,20 & + \\
\hline Equity / Net Loans & 0,20 & + \\
\hline Equity / Total Assets & 0,20 & + \\
\hline
\end{tabular}

Capital Adequacy shields depositors against the risks and promotes the stability of financial systems. Capital has two tiers; tier one is to absorb losses without a bank being required to cease trading, and tier two capital, is to absorb losses if a winding-up happens. Equity capital is categorized as "Tier 1 capital" while subordinated long-term debt is categorized as "Tier 2 capital."

$$
C A R=\frac{\text { Tier One Capital }+ \text { Tier Two Capital }}{\text { Risk Weighted Assets }}
$$

\section{Equation 2. Capital Adequacy Ratio}

This ratio has the most important role in Capital adequacy by being positively related and weight of $40 \%$. As the second ratio in the category, Equity to Total Liabilities measures total equity over total liabilities with a weight of 0.20 and it is positively related to the category ratio. Equity on Net Loans measures the total equity over net loans (Gross Loans - NPLs) that bank allocated to customers and other banks with a weight of 0.20 and positively related to the category ratio. The last ratio in this category is Equity on Total Assets. It measures the total equity (Paid up capital + Reserves) over total assets with a weight of 0.20 and positively related to the category ratio.

\subsection{Asset Quality}

Table 5 presents the diversification of weights to the five ratios under Asset Quality category and their relationships. 
M. Ghazavi - S. Bayraktar 10/2 (2018) 847-874

Table 2. Asset Quality Category Ratios

\begin{tabular}{|l|c|c|}
\hline \multicolumn{2}{|c|}{ ASSET } \\
\hline Variables (\%) & Weight & Relationship \\
\hline ASSET & 0,20 & + \\
\hline Loans / Total Assets & 0,20 & - \\
\hline Fixed Assets / Total Assets & 0,20 & + \\
\hline NPL / Gross Loans & 0,30 & + \\
\hline Specific Provision Reserve / NPLs & 0,15 & + \\
\hline Bearing Assets / Total Assets & 0,15 & + \\
\hline
\end{tabular}

The first ratio in this category, Loans on Total Assets, expresses the proportion of total assets that have been devoted to net loans for the customers. It has a $20 \%$ weight with the positive relationships. The ratio, Fixed Assets on Total Assets, measures the proportion of assets that are less liquid to the Total Assets. This ratio is negatively related to model and it has a weight of 20\%. Nonperforming Loans (NPLs) on Gross Loans is the third ratio in this category. If a loan is overdue at least by 90 days, it is defined as NPL(Nonperforming Loan - NPL). This ratio is negatively related to the model and it has a weight of 30\%. The fourth ratio is the Specific Provision Reserve on NPLs. It shows the proportion of provision that has been taken compare to NPLs. It is positively related and weighted by $15 \%$. The final ratio is Bearing Assets on Total Assets. Bearing assets which are numerator in this ratio consisting of net loans, Interbank loans and deposit with banks, Investment securities, and Derivative financial instruments. Denominator includes all assets. It is positively related and has a weight of $15 \%$.

\subsection{Management Quality}

Six ratios have been applied to evaluate the category of Management Quality which is explained in Table 6. 
M. Ghazavi - S. Bayraktar 10/2 (2018) 847-874

Table 3. Management Quality Category Ratio

\begin{tabular}{|c|c|c|}
\hline \multicolumn{3}{|l|}{ MANAGEMENT } \\
\hline Variables $(\%)$ & Weight & Relationship \\
\hline MANAGEMENT & 0,10 & \\
\hline Current + Saving Deposits / Total Deposits & 0,15 & + \\
\hline Net Income Per Branch (Growth Rate) & 0,20 & + \\
\hline Net Income Per Employee (Growth Rate) & 0,20 & + \\
\hline Non-Interest Exp. + Impairment Exp. / Total Assets & 0,15 & - \\
\hline Net Interest Income / Net Income & 0,15 & + \\
\hline Net Interest Income / Non-Interest Expenses & 0,15 & + \\
\hline
\end{tabular}

The first ratio in this category, Current and Saving Deposits on Total Deposits, has a weight of $15 \%$ and it is positively related to the model. The second ratio indicates that branches are the most important outlets for customers. Therefore, if a bank increases its branches, it is expected that it can reach out to more customers and makes more profit. Growth Rate of Net Income per Branch measures whether or not this expectation is met. In this ratio, the growth rate of the number of branches has been used. In a typical bank, it indicates to what extent every branch has contributed to the creation of net income. It is positively related with the weight of $20 \%$.

The third ratio, Growth Rate of Net Income per Employee shows to what extent more surplus is earned per employee. It can be calculated by dividing profit after tax on the total number of employees. The higher the ratio, the higher the efficiency of the management is. In a typical bank, it shows to what extent every branch has contributed to the creation of net income. It is positively related with the weight of $20 \%$. In the fourth ratio, Non-Interest Expenses and Impairment Expenses on Total Assets, the numerator is non- interest expenses and impairment expenses which include loan impairment charges and securities and other impairment charges (From Income Statement). This ratio is negatively related to the model and has a weight of $15 \%$. In the fifth ratio, Net Interest Income on Net Income, the numerator is net interest income which means total interest income minus total interest expenses and the denominator is net income from the income statement. This ratio has a weight of $15 \%$ and it is positively related. The last ratio, Net Interest Income on Non-Interest Expenses, shows how much net interest income is exceeded from non-interest expenses. The denominator of this ratio represents personnel expenses plus other operating expenses. This ratio is positively related to the model with $15 \%$ weight of management category.

\subsection{Earning Quality}

It shows the quality of a bank's profitability. Table 7 illustrates the details of five ratios in Earning Quality. 
M. Ghazavi - S. Bayraktar 10/2 (2018) 847-874

Table 4. Earning Quality Category Ratios

\begin{tabular}{|l|c|c|}
\hline \multicolumn{2}{|c|}{ EARNINGS } \\
\hline \multicolumn{1}{|c|}{ Variables (\%) } & Weight & Relationship \\
\hline EARNINGS & 0,15 & \\
\hline Net Income/Total Assets & 0,25 & + \\
\hline Net Income/Equity & 0,25 & + \\
\hline Net Interest Margin & 0,20 & + \\
\hline Non-Interest Exp./ Net Interest Inc. + Non-Interest Inc. & 0,15 & - \\
\hline Non-Interest Inc./Net-Interest Inc. + Non-Interest Inc. & 0,15 & + \\
\hline
\end{tabular}

Banks should make sufficient earning in order to maintain their presence in the market for long term and protect their market share. The ratios which are used to evaluate this category are as follows: Net Income on Total Assets or ROA. This ratio has a positive relationship with $25 \%$ weight in the category. The second ratio, Net Income on Equity (ROE = Net Income/ Equity) shows that how efficient a bank uses its own capital. One way a bank might consider improving its ROE is by buying back its shares and replacing them with deposits so the equity which is in the denominator becomes smaller and makes ROE larger. (Christopoulos, et al, 2011, p. 13). This ratio is positively related to a weight of $25 \%$. To measure the earning capacity of the selected banks, Net Interest Margin is computed and analyzed. Spread or Net Interest Income is the difference between the interest income and interest expenses. The higher this ratio the better earning capacity is. This ratio is Net Interest Income on Total Assets Earnings. This ratio is positively related to the category ratio with a weight of $20 \%$. In the numerator of the fourth ratio, Non-Interest Expenses on Net Interest Income and Non-Interest Income, non-interest expenses, consisting of personnel expenses and other operating expenses. The denominator includes net interest income and non-interest income. Net interest income means total interest income minus total interest expenses. This ratio is negatively related to the category ratio with a weight of $15 \%$. The last ratio, Non-Interest Income on Net-Interest Income and Non-Interest Income which is positively related to the category ratio with a weight of $15 \%$.

\subsection{Liquidity Quality}

For a bank, liquidity illustrates its ability to honor its financial obligations promptly. Liquidity problem can endanger the reputation of a bank. Table 8 shows the four Liquidity Quality ratios for this study. 
M. Ghazavi - S. Bayraktar 10/2 (2018) 847-874

Table 5. Liquidity Quality Category Ratios

\begin{tabular}{|c|c|c|}
\hline \multicolumn{3}{|c|}{ LIQUIDITY } \\
\hline Variables (\%) & Weight & Relationship \\
\hline LIQUIDITY & 0,25 & \\
\hline Liquid Assets/Total Assets & 0,30 & + \\
\hline Liquid Assets/Total Foreign Liabilities & 0,25 & + \\
\hline Gross Loans/ Deposit & 0,20 & - \\
\hline Customer Deposits/ Total Funding & 0,25 & + \\
\hline
\end{tabular}

The first ratio of the category, namely, Liquid Assets on Total Assets, is a ratio in which the numerator includes Liquid assets such as investment securities, help a bank to react swiftly to unexpected events demanding more cash and the proportion of it on Total Assets represents how much of bank's assets consists of Liquid assets. Liquid Assets include cash with the central bank, placement with other banks, money market securities and financial assets available for sale. The ratio of liquid assets to total assets shows how liquid a bank's assets. That is to say, it is the ratio of assets due less than 1 year in total assets. This ratio is positively related and weighted as $30 \%$. The second ratio of the category, Liquid Assets on Total Foreign Liabilities, shows that how many liquid assets could cover liabilities that are held in foreign currencies such as Euro, US Dollar. This ratio is positively related to the model with a weight of $25 \%$. If Gross Loans on Deposits as the third ratio of the category is lower, bank enjoys a better level of liquidity to cover the obligations. This ratio is negatively related to the category with a weight of $20 \%$. The last ratio of this category is Customer Deposits on Total Funding which is positively related to the category with a weight of $25 \%$.

\subsection{Sensitivity to Market Risk}

Changes in variables such as exchange rate, interest rate, equity price or commodity price, can exert a negative effect on income and capital of the financial institutions. Many financial institutions consider changes in interest rates as market risk. This "S" part of the CAMELS informs managers about where there are some supervision problems. (Grier, 2007) Changes of the abovementioned variables may have significant effects on the bank assets and profits. Banks nowadays have to change themselves because of market demands. (Christopoulos, Mylonakis, \& Diktapanidis, 2011)

This component has been included in CAMEL component in 1997 and started to be used in performance evaluation of banks. This component helps to measure the profitability of the banks and the level of risk at the interest rates and exchange rates may affect the capital adequacy. Three ratios have been chosen for this category which is as follows in Table 6. 
M. Ghazavi - S. Bayraktar 10/2 (2018) 847-874

Table 6. Earning Quality Category Ratios

\begin{tabular}{|c|c|c|}
\hline \multicolumn{3}{|c|}{ SENSITIVITY } \\
\hline Variables(\%) & Weight & Relationship \\
\hline SENSITIVITY & 0,10 & \\
\hline Securities Portfolio/Total Assets & 0,30 & - \\
\hline Bearing Assets/Costly Liabilities & 0,30 & + \\
\hline Net Interest Income/Total Assets & 0,40 & + \\
\hline
\end{tabular}

The first ratio of the category is Securities Portfolio on Total Assets. This is a ratio in which the numerator consists of financial assets held for trading, available for sale, held to maturity and investments in associates and subsidiaries. The ratio tells the correlation of banks securities with total assets and provides us the percentage change of its portfolio with respect to alteration in interest rates or other issues associated with the issuer of the securities. The higher value of this ratio means that the bank's portfolio is subjected to market risk at greater scale. This ratio is negatively related to the category ratio with a weight of $30 \%$.

The second ratio of the category, Bearing Assets on Liabilities, which is total earning assets over total interest-bearing liabilities. This ratio is positively related to the category ratio with a weight of $30 \%$. The third ratio of the category is Net Interest Income on Total Assets which is positively related to the category with a weight of $40 \%$.

\section{ANALYSIS AND DISCUSSION}

\subsection{Analysis for the long-term period}

Most of the data used in this study has been collected from official sources such as Bank Association of Turkey, Banking Regulation and Supervision Agency (BRSABDDK) and also official websites of each bank. Table 7 shows the overall CAMELS rating for all six banks for twelve years (2005-2016). It is seen that Ziraat Bank has the best rates for most of the years analyzed (exceptions are 2005 and 2008). İşbank is at the top in 2005 (46.96\%) and 2008 (36.98\%).

Since decimal figures by themselves cannot demonstrate properly small changes because they usually have to be round up, CAMELS ratings have been transformed to index numbers, therefore, smallest changes of the index in the course of time will be fully understandable and absorbable. Table 8 takes 2005 as the base year with an index of 100 and the other rates can be easily compared to this initial value. Figure 3, on the other hand, illustrates the trend of these indices for twelve years. Although there are some increases in 2007 and 2009, it is obvious that the CAMELS ratio for all banks deteriorates after 2009. If we drill down to find the specific ratios which have caused such a deterioration, we see that all individual ratios affecting the overall rate have an adverse influence. In other words, we observe a deterioration in the banks' performance 
in all aspects, including capital adequacy, asset quality, management, liquidity, earing quality, and sensitivity to market risk.

The banking sector appears to have experienced some dampening events which show themselves in a downward trend of the financial ratios and CAMELS rating as well. Actually during recent years, global liquidity conditions tightened, federal interest rate in the U.S. was perceived to rise and even in practice it rose several times resulting in appreciation USD against many currencies including TRY, together with rising political and geopolitical risks, and an upward change in domestic deposit rates and bond yields altogether played a dampening role in Turkish economy in a way that even Real GDP growth was moderate while it was beforehand also below the long run economic growth and banks situations somehow moderated. Almost one-third of bank loans and more than two-fifths of deposits are in foreign exchange, and when national currency depreciates, it affects negatively the financial market specifically the money market in Turkey, for instance, we witness that deposit growth slowed down to keep up with credit growth in recent years which reasonably has a pushing effect on rising the loan-to-deposit ratio above the $100 \%$ threshold. NPL ratio also moved up, since many households and businesses faced financial difficulties due to the rise of foreign-currency debt-service costs. Subsequently, banks' profits rise was smaller compared to the past. Return-on-

Table 7. CAMELS Rating for All Banks from 2005 to 2016 (In percentages)

\begin{tabular}{|l|c|c|c|c|c|c|c|c|c|c|c|c|}
\hline \multicolumn{1}{|c|}{ Bank } & 2005 & 2006 & 2007 & 2008 & 2009 & 2010 & 2011 & 2012 & 2013 & 2014 & 2015 & 2016 \\
\hline $\begin{array}{l}\text { Ziraat } \\
\text { Bank }\end{array}$ & 45,3 & 46,11 & 50,22 & 32,02 & 42,20 & 39,62 & 33,16 & 35,92 & 30,68 & 29,73 & 27,21 & 29,32 \\
\hline Halkbank & 28,52 & 31,93 & 31,54 & 23,97 & 27,62 & 26,32 & 25,12 & 27,27 & 23,85 & 19,94 & 21,33 & 21,94 \\
\hline $\begin{array}{l}\text { Garanti } \\
\text { Bank }\end{array}$ & 30,70 & 28,39 & 34,74 & 28,47 & 40,16 & 35,15 & 32,61 & 31,51 & 24,55 & 24,13 & 23,75 & 25,38 \\
\hline Isşbank & 46,96 & 42,72 & 43,78 & 36,98 & 40,12 & 35,37 & 30,43 & 29,04 & 24,65 & 24,81 & 23,85 & 26,49 \\
\hline Akbank & 37,87 & 32,47 & 36,50 & 27,07 & 38,65 & 36,90 & 32,62 & 32,55 & 26,09 & 25,61 & 25,76 & 27,36 \\
\hline Şekerbank & 31,97 & 28,95 & 30,24 & 25,16 & 26,65 & 22,92 & 22,14 & 26,83 & 19,54 & 21,16 & 26,23 & 28,51 \\
\hline
\end{tabular}

Table 8. CAMELS Performance Index for All Banks during 2005-2016

\begin{tabular}{|c|c|c|c|c|c|c|c|c|c|c|c|c|}
\hline & 2005 & 2006 & 2007 & 2008 & 2009 & 2010 & 2011 & 2012 & 2013 & 2014 & 2015 & 2016 \\
\hline $\begin{array}{l}\text { Ziraat } \\
\text { Bank }\end{array}$ & $\begin{array}{c}100,0 \\
0\end{array}$ & 101,77 & 110,84 & 70,67 & 93,15 & 87,44 & 73,20 & 79,28 & 67,72 & 65,62 & 60,06 & 64,71 \\
\hline Halkbank & $\begin{array}{c}100,0 \\
0\end{array}$ & 111,98 & 110,58 & 84,05 & 96,86 & 92,28 & 88,10 & 95,64 & 83,64 & 69,94 & 74,80 & 76,95 \\
\hline $\begin{array}{l}\text { Garanti } \\
\text { Bank }\end{array}$ & $\begin{array}{c}100,0 \\
0 \\
\end{array}$ & 92,49 & 113,17 & 92,76 & 130,81 & 114,49 & 106,24 & 102,66 & 79,99 & 78,61 & 77,37 & 82,66 \\
\hline İşbank & $\begin{array}{c}100,0 \\
0 \\
\end{array}$ & 90,96 & 93,23 & 78,75 & 85,43 & 75,31 & 64,79 & 61,84 & 52,48 & 52,83 & 50,77 & 56,41 \\
\hline Akbank & $\begin{array}{c}100,0 \\
0\end{array}$ & 85,73 & 96,38 & 71,47 & 102,06 & 97,44 & 86,13 & 85,95 & 68,90 & 67,62 & 68,02 & 72,24 \\
\hline Şekerbank & $\begin{array}{c}100,0 \\
0\end{array}$ & 90,56 & 94,58 & 78,69 & 83,36 & 71,69 & 69,26 & 83,93 & 61,13 & 66,18 & 82,06 & 89,19 \\
\hline
\end{tabular}




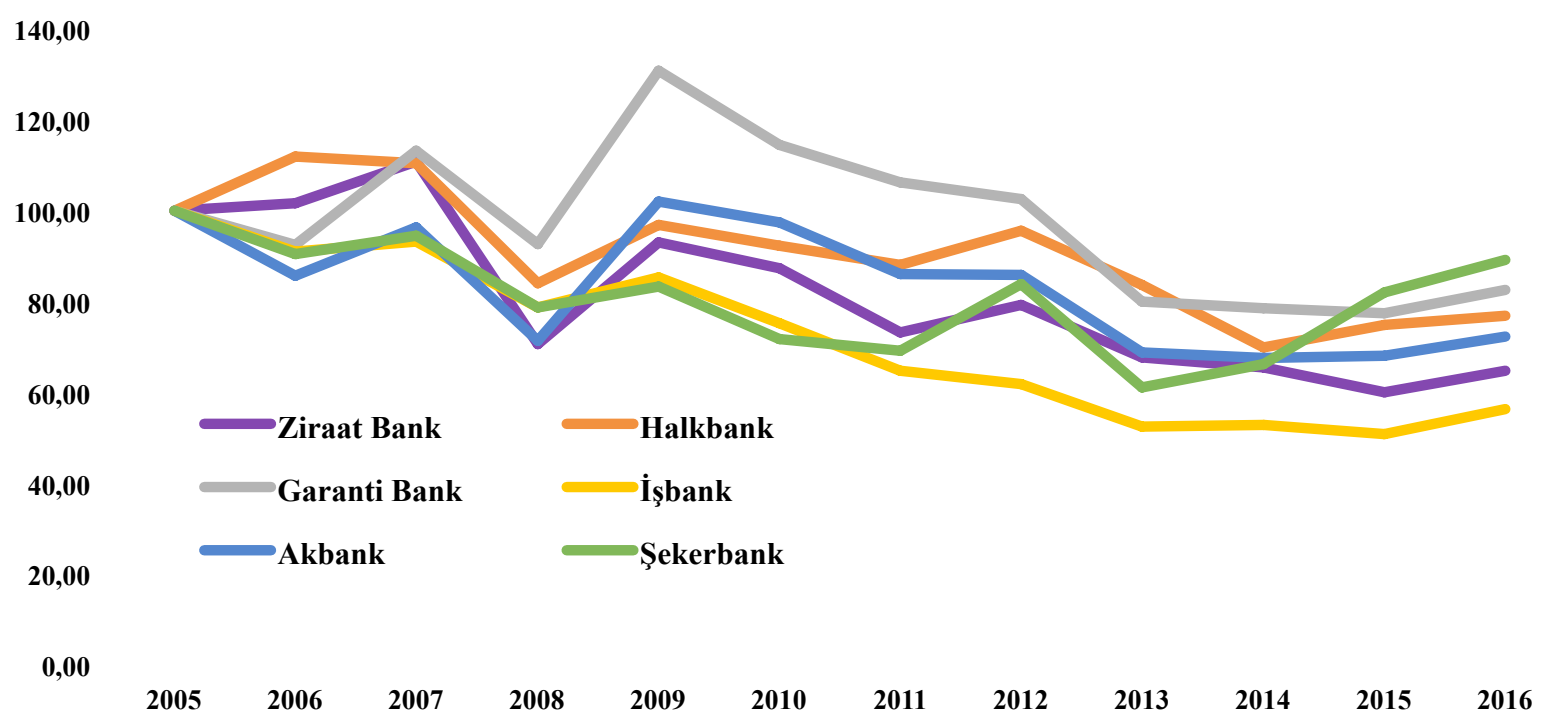

Figure 3. CAMELS Performance Index for All Banks during 2005-2016

equity (ROE) went slightly down and Return-on-assets (ROA) fell below which is not enough to encourage the recapitalization in banks in order to leverage a more expanded balance sheet and create financing opportunities for companies and households. The average capital-adequacy ratio has fallen but remains comfortably above the $12 \%$ as the necessary threshold of the BRSA (Economist Intelligence Unit, 2016).

\subsection{Analysis for the recent period}

In this part of the study, we would like to focus on more recent years of the sample period. First, we compare the banks for the very recent year of 2016 and then with respect to the average value of the three years of 2014, 2015 and 2016. First, for all six banks, CAMELS ratio has been calculated for the last year of 2016. The results are shown in Table 9. If we look at the categories first, as for Capital category, banks are ranked as follows: Garanti Bank, İşbank, Akbank, Ziraat Bank, Şekerbank and Halkbank with a rate of $15.66 \%, 14.51 \%, 14.32 \%, 13.67 \%, 12.63 \%$ and $11.80 \%$ respectively. However, obviously, the values are quite close to each other. As far as the Asset category is concerned, the priority order for the banks under study is according to the following list: Ziraat Bank (39.24\%), Akbank (38.42\%), Garanti Bank (37.36\%), Halkbank (36.83\%), İşbank (36.74\%), Şekerbank (31.97\%). Still, we observe that the values are quite close to each other. For the Management category, Şekerbank stands first with $169.98 \%$, the other banks are listed respectively as follows: Ziraat Bank (91.22\%), İşbank (88.67\%), Garanti Bank (87.11\%), Akbank (83.86\%), Halkbank $(77.98 \%)$. However, for this category, the values are quite different that's why the views and emphasis of the management team for each individual bank are different in terms of low costly deposit mobilization, net income per branch and employee, non-interest expenses and net interest income. Actually based on their strategic views, they make management decisions which affect their performance quite differently. When we take into consideration the Earnings category the priority order will be disclosed as follows: 
Akbank (4.75\%), Ziraat Bank (3.87\%), Garanti Bank (2.48\%), İşbank (1.94\%), Halkbank $(1.57 \%)$ and Şekerbank is $-1.59 \%$. As for the Liquidity category, the highest rank belongs to Ziraat Bank (25.79\%) and rest is as follows Akbank (20.53\%), İşbank (17.55\%), Garanti Bank (11.15\%), Halkbank (6.48\%) and Şekerbank (-0.14\%). In terms of Liquidity, we can again observe that capabilities are quite different for the banks. In case of the Sensitivity category, our set of banks shows the following priority order: Garanti Bank (29.00\%), Şekerbank with 28.72\%, İşbank (26.98\%), Ziraat Bank (25.88\%), Halkbank(25.65\%) and Akbank (25.78\%). Finally, the overall rate for banks shows that Ziraat Bank is the first with $29.32 \%$ and Şekerbank is the second with 28.51\%, following them Akbank has 27.36\%, İşbank has 26.49\%, Garanti Bank has $25.38 \%$ and Halkbank finally has $21.94 \%$ rating. The overall rating for the banks illustrates that they have negligible difference in terms of the average value of the rating. In other words, the values of overall rating all remain within a small range for the year of 2016. It is just because that some differences within the categories have been canceled off when we take the average of these ratios to compute the overall CAMELS rating. Although the chosen banks have different financial structures, most probably just because they have tried to keep themselves within the boundaries of prudential rules and standards defined by BRSA, they ended up with quite similar CAMELS ratios for the year of 2016. Besides, it may also indicate that supervision of BRSA has proved satisfactorily efficient and effective.

Table 9. CAMELS Rating for Ziraat Bank 2016 (Numbers are rounded) COMPARATIVE RATIOS RELATED TO BANKS UNDER STUDY (2016)

\begin{tabular}{|c|c|c|c|c|c|c|c|c|c|}
\hline \multicolumn{10}{|c|}{ COMPARATIVE RATIOS RELATED TO BANKS UNDER STUDY (2016) } \\
\hline \multirow[t]{2}{*}{ No. } & Weight & Ratios & \multirow[t]{2}{*}{$\begin{array}{c}\text { Relation } \\
\text { ship }\end{array}$} & \multirow{2}{*}{$\begin{array}{c}\text { Ziraat Bank } \\
13,67 \%\end{array}$} & \multirow{2}{*}{$\begin{array}{r}\text { Halkbank } \\
11,80 \%\end{array}$} & \multirow{2}{*}{$\begin{array}{l}\text { İşbank } \\
14,51 \%\end{array}$} & \multirow{2}{*}{$\begin{array}{l}\text { Akbank } \\
14,32 \%\end{array}$} & \multirow{2}{*}{$\begin{array}{c}\text { Garanti Bank } \\
15,66 \%\end{array}$} & \multirow{2}{*}{$\begin{array}{c}\text { Şekerbank } \\
12,63 \%\end{array}$} \\
\hline & Overall Weight & Capital & & & & & & & \\
\hline & 0,20 & & & & & & & & \\
\hline 1 & 0,40 & Capital Adequacy Ratio(\%) (+) & + & $14,55 \%$ & $13,08 \%$ & $15,17 \%$ & $14,30 \%$ & $16,21 \%$ & $13,11 \%$ \\
\hline 2 & 0,20 & Equity/ Total Liabilities (\%) (+) & + & $12,02 \%$ & $10,14 \%$ & $13,05 \%$ & $12,75 \%$ & $14,29 \%$ & $11,90 \%$ \\
\hline 3 & 0,20 & Equity/ Net Loans $(\%)(+)$ & + & $16,50 \%$ & $13,46 \%$ & $17,61 \%$ & $18,94 \%$ & $19,10 \%$ & $14,39 \%$ \\
\hline \multirow[t]{2}{*}{4} & 0,20 & Equity/Total Assets(\%) (+) & + & $10,73 \%$ & $9,21 \%$ & $11,54 \%$ & $11,31 \%$ & $12,51 \%$ & $10,63 \%$ \\
\hline & Overall Weight & Asset & & $39,24 \%$ & $36,83 \%$ & $36,74 \%$ & $38,42 \%$ & $37,36 \%$ & $31,97 \%$ \\
\hline & 0,20 & & & & & & & & \\
\hline 5 & 0,20 & Loans/Total Assets(\%)(+) & + & $65,03 \%$ & $68,42 \%$ & $65,55 \%$ & $59,71 \%$ & $65,47 \%$ & $73,92 \%$ \\
\hline 6 & 0,20 & Fixed Assets/Total Assets(\%)(-) & - & $1,64 \%$ & $1,16 \%$ & $1,43 \%$ & $0,34 \%$ & $1,64 \%$ & $4,44 \%$ \\
\hline 7 & 0,30 & NPL / Gross Loans (\%)(-) & - & $1,78 \%$ & $3,14 \%$ & $2,36 \%$ & $2,57 \%$ & $2,76 \%$ & $5,78 \%$ \\
\hline 8 & 0,15 & Specific Provision Reserve/ NPL (\%)(+) & + & $94,04 \%$ & $77,12 \%$ & $77,48 \%$ & $96,37 \%$ & $80,93 \%$ & $45,91 \%$ \\
\hline \multirow[t]{3}{*}{9} & 0,15 & Bearing Assets/Total Assets(\%)(+) & + & $86,63 \%$ & $85,01 \%$ & $86,71 \%$ & $85,74 \%$ & $88,54 \%$ & $86,14 \%$ \\
\hline & Overall Weight & Management & & $91,22 \%$ & $77,98 \%$ & $88,67 \%$ & $83,86 \%$ & $87,11 \%$ & $169,98 \%$ \\
\hline & 0,10 & & & & & & & & \\
\hline 10 & 0,15 & Current + Savings Deposits/ Total Deposits (\%)(+) & + & $57,70 \%$ & $43,51 \%$ & $53,19 \%$ & $46,08 \%$ & $50,93 \%$ & $53,90 \%$ \\
\hline 11 & 0,20 & Net Income Per Branch (Growth Rate\%)(+) & + & $27,39 \%$ & $8,77 \%$ & $52,84 \%$ & $62,18 \%$ & $50,69 \%$ & $34,47 \%$ \\
\hline 12 & 0,20 & Net Income Per Employee (Growth Rate \%)(+) & + & $30,89 \%$ & $11,46 \%$ & $54,97 \%$ & $53,48 \%$ & $48,87 \%$ & $37,74 \%$ \\
\hline 13 & 0,15 & Non-Interest Exp. + Impairment Exp/ Total Assets (\%)(-) & - & $2,42 \%$ & $2,58 \%$ & $2,92 \%$ & $2,40 \%$ & $3,14 \%$ & $5,94 \%$ \\
\hline 14 & 0,15 & Net Interest Income / Net Income $(+)$ & + & $212,10 \%$ & $271,93 \%$ & $230,52 \%$ & $175,47 \%$ & $218,85 \%$ & $866,65 \%$ \\
\hline 15 & 0,15 & Net Interest Income / Non-interest Expenses $(+)$ & + & $263,03 \%$ & $180,02 \%$ & $166,57 \%$ & $185,67 \%$ & $181,37 \%$ & $122,32 \%$ \\
\hline \multicolumn{2}{|r|}{ Overall Weight } & Earnings & & $3,87 \%$ & $1,57 \%$ & $1,94 \%$ & $4,75 \%$ & $2,48 \%$ & $-1,59 \%$ \\
\hline & 0,15 & & & & & & & & \\
\hline 16 & 0,25 & Net Income/Total Assets(\%)(+) & + & $1,84 \%$ & $1,11 \%$ & $1,51 \%$ & $1,67 \%$ & $1,78 \%$ & $0,53 \%$ \\
\hline 17 & 0,25 & Net Income/Equity(\%)(+) & + & $17,13 \%$ & $12,00 \%$ & $13,07 \%$ & $14,77 \%$ & $14,27 \%$ & $4,94 \%$ \\
\hline 18 & 0,20 & Net Interest Margin $(\%)(+)$ & + & $4,50 \%$ & $3,54 \%$ & $4,01 \%$ & $3,42 \%$ & $4,41 \%$ & $5,29 \%$ \\
\hline 19 & 0,15 & Non-Interest Exp./ Net Interest Inc.+ Non-Interest Inc. (\%)(- & - & $30,80 \%$ & $41,45 \%$ & $43,79 \%$ & $35,10 \%$ & $41,26 \%$ & $57,03 \%$ \\
\hline 20 & 0,15 & Non-Interest Inc./Net-Interest Inc. + Non-Interest Inc. $(\%)(+)$ & + & $18,99 \%$ & $25,37 \%$ & $27,06 \%$ & $34,83 \%$ & $25,17 \%$ & $30,24 \%$ \\
\hline \multicolumn{2}{|r|}{ Overall Weight } & Liquidity & & $25,79 \%$ & $6,48 \%$ & $17,55 \%$ & $20,53 \%$ & $11,15 \%$ & $-0,14 \%$ \\
\hline & 0,25 & & & & & & & & \\
\hline 21 & 0,30 & Liquid Assets/Total Assets(\%)(+) & + & $28,43 \%$ & $20,16 \%$ & $25,67 \%$ & $28,60 \%$ & $19,84 \%$ & $12,47 \%$ \\
\hline 22 & 0,25 & Liquid Assets/Total Foreign Liabilites (\%)(+) & + & $90,06 \%$ & $41,31 \%$ & $70,83 \%$ & $68,64 \%$ & $49,92 \%$ & $2,63 \%$ \\
\hline 23 & 0,20 & Gross Loans/ Deposit (\%)(-) & - & $112,28 \%$ & $128,30 \%$ & $122,41 \%$ & $109,00 \%$ & $121,46 \%$ & $119,05 \%$ \\
\hline 24 & 0,25 & Customer Deposits/ Total Funding (\%)(+) & + & $68,82 \%$ & $63,07 \%$ & $66,49 \%$ & $66,38 \%$ & $68,04 \%$ & $77,06 \%$ \\
\hline \multicolumn{2}{|r|}{ Overall Weight } & Sensitivity & & $25,88 \%$ & $25,65 \%$ & $26,98 \%$ & $25,78 \%$ & $29,00 \%$ & $28,72 \%$ \\
\hline & 0,10 & & & & & & & & \\
\hline 25 & 0,30 & Securities Portfolio/Total Assets(\%)(-) & - & $20,04 \%$ & $15,87 \%$ & $19,82 \%$ & $19,20 \%$ & $17,20 \%$ & $11,09 \%$ \\
\hline 26 & 0,30 & Bearing Assets/Costly Liabilities(\%)(+) & + & $101,10 \%$ & $97,36 \%$ & $105,12 \%$ & $101,22 \%$ & $108,67 \%$ & $100,74 \%$ \\
\hline 27 & 0,40 & Net Interest Income/Total Assests(\%)(+) & + & $3,90 \%$ & $3,01 \%$ & $3,48 \%$ & $2,93 \%$ & $3,91 \%$ & $4,56 \%$ \\
\hline OVE & RALS RATIES & FOR ALI BANXS 2016 & & $29,32 \%$ & $21,94 \%$ & $26,49 \%$ & $27,36 \%$ & $25,38 \%$ & $28,51 \%$ \\
\hline
\end{tabular}


To get a better perspective, in this part of the study, rather than only looking at the very last year, we will look at the average of what happened during last three years of the sample period, namely 2014-2016. Table 10 illustrates the average of Capital Adequacy category rate for each bank during last three years of the study. Based on the average of these three years, each bank has been ranked from 1 to 6 . Then by taking the average of ranks for each ratio, we can get a new order from 1 to 6 which has been illustrated in the last two columns. As the result shows Garanti Bank ranked on the top position followed by İşbank, and Halkbank got the lowest rank.

Table 10. Capital Adequacy Category Components Ratio and Rank for All Banks (Average of 2014-2016)

\begin{tabular}{|l|c|c|c|c|c|c|c|c|c|c|}
\cline { 2 - 13 } \multicolumn{1}{c|}{} & \multicolumn{2}{c|}{$\begin{array}{c}\text { Capital } \\
\text { Adequacy } \\
\text { Ratio(\%) }(+)\end{array}$} & \multicolumn{2}{c|}{$\begin{array}{c}\text { Equity/ Total } \\
\text { Liabilities (\%) } \\
(+)\end{array}$} & \multicolumn{2}{c|}{$\begin{array}{c}\text { Equity/ Net } \\
\text { Loans (\%) (+) }\end{array}$} & \multicolumn{2}{c|}{$\begin{array}{c}\text { Equity/Total } \\
\text { Assets(\%) (+) }\end{array}$} & \multicolumn{2}{c|}{$\begin{array}{c}\text { Capital Category } \\
\text { Rank }\end{array}$} \\
\hline Bank & $\%$ & Rank & $\%$ & Rank & $\%$ & Rank & $\%$ & Rank & Avg & Rank \\
\hline Ziraat Bank & $15,95 \%$ & 1 & $12,22 \%$ & 4 & $17,83 \%$ & 4 & $10,89 \%$ & 4 & 3,25 & 4 \\
\hline Halkbank & $13,51 \%$ & 6 & $11,20 \%$ & 6 & $15,01 \%$ & 6 & $10,07 \%$ & 6 & 6,00 & 6 \\
\hline $\begin{array}{l}\text { Garanti } \\
\text { Bank }\end{array}$ & $15,47 \%$ & 3 & $13,88 \%$ & 1 & $19,32 \%$ & 1 & $12,19 \%$ & 1 & 1,50 & 1 \\
\hline İşbank & $15,59 \%$ & 2 & $13,42 \%$ & 2 & $18,14 \%$ & 3 & $11,83 \%$ & 2 & 2,25 & 2 \\
\hline Akbank & $14,68 \%$ & 4 & $13,17 \%$ & 3 & $19,23 \%$ & 2 & $11,63 \%$ & 3 & 3,00 & 3 \\
\hline Şekerbank & $13,79 \%$ & 5 & $12,06 \%$ & 5 & $15,28 \%$ & 5 & $10,76 \%$ & 5 & 5,00 & 5 \\
\hline
\end{tabular}

Asset Quality Category average was expressed in Table 11 which shows the average of five ratios of this category and it has been ranked from 1 to 6 . Akbank (2.40) was at the top position with the lowest average of the rank followed by Isşbank (3.00) and Garanti Bank (3.20).

Table 11. Asset Quality Category Components Ratio and Rank for All Banks (Average of 2014-2016)

\begin{tabular}{|c|c|c|c|c|c|c|c|c|c|c|c|c|}
\hline \multirow[b]{2}{*}{ Bank } & \multicolumn{2}{|c|}{$\begin{array}{c}\text { Loans/Total } \\
\text { Assets( }(\%)(+)\end{array}$} & \multicolumn{2}{|c|}{$\begin{array}{c}\text { Fixed } \\
\text { Assets/Total } \\
\text { Assets(\%)(-) }\end{array}$} & \multicolumn{2}{|c|}{$\begin{array}{l}\text { NPLs / Gross } \\
\text { Loans }(\%)(-)\end{array}$} & \multicolumn{2}{|c|}{$\begin{array}{c}\text { Specific } \\
\text { Provision } \\
\text { Reserve/ NPLs } \\
(\%)(+)\end{array}$} & \multicolumn{2}{|c|}{$\begin{array}{c}\text { Bearing } \\
\text { Assets/Total } \\
\text { Assets }(\%)(+)\end{array}$} & \multicolumn{2}{|c|}{$\begin{array}{c}\text { Asset } \\
\text { Category } \\
\text { Rank }\end{array}$} \\
\hline & $\%$ & Rank & $\%$ & Rank & $\%$ & Rank & $\%$ & Rank & $\%$ & Rank & Avg & Rank \\
\hline $\begin{array}{l}\text { Ziraat } \\
\text { Bank }\end{array}$ & $61,34 \%$ & 5 & $1,76 \%$ & 5 & $1,78 \%$ & 1 & $79,15 \%$ & 3 & $85,67 \%$ & 4 & 3,60 & 4 \\
\hline Halkbank & $67,14 \%$ & 2 & $1,08 \%$ & 2 & $3,25 \%$ & 5 & $72,86 \%$ & 5 & $85,23 \%$ & 5 & 3,80 & 5 \\
\hline $\begin{array}{l}\text { Garanti } \\
\text { Bank } \\
\end{array}$ & $63,09 \%$ & 4 & $1,30 \%$ & 4 & $2,63 \%$ & 4 & $80,98 \%$ & 2 & $87,17 \%$ & 2 & 3,20 & 3 \\
\hline İşbank & $65,21 \%$ & 3 & $1,28 \%$ & 3 & $1,96 \%$ & 2 & $76,50 \%$ & 4 & $86,56 \%$ & 3 & 3,00 & 2 \\
\hline Akbank & $60,47 \%$ & 6 & $0,42 \%$ & 1 & $2,24 \%$ & 3 & $95,17 \%$ & 1 & $87,57 \%$ & 1 & 2,40 & 1 \\
\hline Şekerbank & $70,49 \%$ & 1 & $4,25 \%$ & 6 & $5,72 \%$ & 6 & $53,88 \%$ & 6 & $83,74 \%$ & 6 & 5,00 & 6 \\
\hline
\end{tabular}


According to results for Management Efficiency shown in Table 12, Ziraat Bank has the best rank with the average rank of 2.00 and Şekerbank had the worst rank with the average rank of 4.33 .

Table 12. Management Efficiency Category Components Ratio and Rank for All Banks (Average of 2014-2016)

\begin{tabular}{|c|c|c|c|c|c|c|c|c|c|c|c|c|c|c|}
\hline \multirow[b]{2}{*}{ Bank } & \multicolumn{2}{|c|}{$\begin{array}{c}\text { Current }+ \\
\text { Savings } \\
\text { Deposits/ Total } \\
\text { Deposits } \\
(\%)(+)\end{array}$} & \multicolumn{2}{|c|}{$\begin{array}{c}\text { Net Income Per } \\
\text { Branch } \\
(\text { Growth } \\
\text { Rate } \%)(+)\end{array}$} & \multicolumn{2}{|c|}{$\begin{array}{l}\text { Net Income } \\
\text { Per } \\
\text { Employee } \\
(\text { Growth Rate } \\
\%)(+)\end{array}$} & \multicolumn{2}{|c|}{$\begin{array}{l}\text { Non-Interest } \\
\text { Exp. }{ }^{+} \\
\text {Impairment } \\
\text { Exp/ Total } \\
\text { Assets }(\%)(-)\end{array}$} & \multicolumn{2}{|c|}{$\begin{array}{l}\text { Net Interest } \\
\text { Income / Net } \\
\text { Income }(+)\end{array}$} & \multicolumn{2}{|c|}{$\begin{array}{c}\text { Net Interest } \\
\text { Income / Non- } \\
\text { interest } \\
\text { Expenses }(+) \\
\end{array}$} & \multicolumn{2}{|c|}{$\begin{array}{c}\text { Management } \\
\text { Category Rank }\end{array}$} \\
\hline & $\%$ & Rank & $\%$ & Rank & $\%$ & $\begin{array}{c}\text { Ran } \\
\mathrm{k}\end{array}$ & $\%$ & Rank & $\%$ & Rank & $\%$ & Rank & Avg & Rank \\
\hline $\begin{array}{l}\text { Ziraat } \\
\text { Bank } \\
\end{array}$ & $\begin{array}{c}58,47 \\
\% \\
\end{array}$ & 1 & $\begin{array}{c}21,91 \\
\%\end{array}$ & 2 & $\begin{array}{c}25,11 \\
\%\end{array}$ & 1 & $2,28 \%$ & 1 & $\begin{array}{c}209,38 \\
\% \\
\end{array}$ & 6 & $\begin{array}{c}224,99 \\
\% \\
\end{array}$ & 1 & 2,00 & 1 \\
\hline Halkbank & $\begin{array}{c}45,83 \\
\% \\
\end{array}$ & 6 & $\begin{array}{c}-4,51 \\
\% \\
\end{array}$ & 6 & $\begin{array}{c}-4,58 \\
\% \\
\end{array}$ & 6 & $2,60 \%$ & 2 & $\begin{array}{c}249,42 \\
\% \\
\end{array}$ & 2 & $\begin{array}{c}171,15 \\
\% \\
\end{array}$ & 3 & 4,17 & 5 \\
\hline $\begin{array}{l}\text { Garanti } \\
\text { Bank } \\
\end{array}$ & $\begin{array}{c}49,26 \\
\% \\
\end{array}$ & 4 & $\begin{array}{c}21,86 \\
\%\end{array}$ & 3 & $\begin{array}{c}18,86 \\
\%\end{array}$ & 3 & $3,10 \%$ & 5 & $\begin{array}{c}240,90 \\
\%\end{array}$ & 4 & $\begin{array}{c}165,45 \\
\% \\
\end{array}$ & 4 & 3,83 & 4 \\
\hline İșbank & $\begin{array}{c}53,58 \\
\% \\
\end{array}$ & 2 & $\begin{array}{c}15,26 \\
\% \\
\end{array}$ & 4 & $\begin{array}{c}16,39 \\
\%\end{array}$ & 4 & $2,97 \%$ & 4 & $\begin{array}{c}247,46 \\
\% \\
\end{array}$ & 3 & $\begin{array}{c}146,49 \\
\%\end{array}$ & 5 & 3,67 & 3 \\
\hline Akbank & $\begin{array}{c}48,70 \\
\%\end{array}$ & 5 & $\begin{array}{c}24,39 \\
\%\end{array}$ & 1 & $\begin{array}{c}23,50 \\
\%\end{array}$ & 2 & $2,64 \%$ & 3 & $\begin{array}{c}211,59 \\
\%\end{array}$ & 5 & $\begin{array}{c}180,95 \\
\% \\
\end{array}$ & 2 & 3,00 & 2 \\
\hline Şekerbank & $\begin{array}{c}52,91 \\
\% \\
\end{array}$ & 3 & $\begin{array}{c}-3,83 \\
\% \\
\end{array}$ & 5 & $\begin{array}{c}-4,33 \\
\% \\
\end{array}$ & 5 & $5,46 \%$ & 6 & $\begin{array}{c}777,48 \\
\% \\
\end{array}$ & 1 & $\begin{array}{c}122,82 \\
\% \\
\end{array}$ & 6 & 4,33 & 6 \\
\hline
\end{tabular}

In Earning Quality category (Table 13), Akbank (2.80) had the lowest average rank for the years 2014-2016 and stood at the top position while Şekerbank (4.40) and Halkbank (4.40) had the highest average rank.

Table 13. Earning Quality Category Components Ratio and Rank for All Banks (Average of 2014-2016)

\begin{tabular}{|c|c|c|c|c|c|c|c|c|c|c|c|c|}
\hline \multirow[b]{2}{*}{ Bank } & \multicolumn{2}{|c|}{$\begin{array}{c}\text { Net } \\
\text { Income/Total } \\
\text { Assets }(\%)(+) \\
\end{array}$} & \multicolumn{2}{|c|}{$\begin{array}{c}\text { Net } \\
\text { Income/Equity } \\
(\%)(+) \\
\end{array}$} & \multicolumn{2}{|c|}{$\begin{array}{c}\text { Net Interest } \\
\text { Margin }(\%)(+)\end{array}$} & \multicolumn{2}{|c|}{$\begin{array}{l}\text { Non-Interest } \\
\text { Exp./ Net } \\
\text { Interest Inc. }+ \\
\text { Non-Interest } \\
\text { Inc. }(\%)(-) \\
\end{array}$} & \multicolumn{2}{|c|}{$\begin{array}{l}\text { Non-Interest } \\
\text { Inc./Net- } \\
\text { Interest Inc. }+ \\
\text { Non-Interest } \\
\text { Inc. }(\%)(+) \\
\end{array}$} & \multicolumn{2}{|c|}{$\begin{array}{c}\text { Earning } \\
\text { Category Rank }\end{array}$} \\
\hline & $\%$ & Rank & $\%$ & Rank & $\%$ & Rank & $\%$ & Rank & $\%$ & Rank & Avg & Rank \\
\hline $\begin{array}{l}\text { Ziraat } \\
\text { Bank }\end{array}$ & $1,73 \%$ & 1 & $15,90 \%$ & 1 & $4,22 \%$ & 2 & $36,16 \%$ & 1 & $19,68 \%$ & 6 & 2,20 & 1 \\
\hline Halkbank & $1,25 \%$ & 5 & $12,42 \%$ & 4 & $3,64 \%$ & 5 & $43,51 \%$ & 3 & $25,66 \%$ & 5 & 4,40 & 5,5 \\
\hline $\begin{array}{l}\text { Garanti } \\
\text { Bank }\end{array}$ & $1,53 \%$ & 2 & $12,52 \%$ & 3 & $4,18 \%$ & 3 & $44,79 \%$ & 4 & $26,18 \%$ & 4 & 3,20 & 3 \\
\hline İşbank & $1,35 \%$ & 4 & $11,41 \%$ & 5 & $3,80 \%$ & 4 & $48,80 \%$ & 5 & $28,99 \%$ & 2 & 4,00 & 4 \\
\hline Akbank & $1,49 \%$ & 3 & $12,86 \%$ & 2 & $3,56 \%$ & 6 & $38,07 \%$ & 2 & $31,28 \%$ & 1 & 2,80 & 2 \\
\hline Şekerbank & $0,67 \%$ & 6 & $6,12 \%$ & 6 & $5,37 \%$ & 1 & $59,14 \%$ & 6 & $27,35 \%$ & 3 & 4,40 & 5,5 \\
\hline
\end{tabular}


In Liquidity category (Table 14), Ziraat Bank was at the top position with the lowest average rank of 1.25 followed by Akbank(3.25) and Garanti Bank (3.50). Halkbank (5.00) was in the last row.

Table 14. Liquidity Category Components Ratio and Rank for All Banks (Average of 20142016)

\begin{tabular}{|c|c|c|c|c|c|c|c|c|c|c|}
\hline \multirow[b]{2}{*}{ Bank } & \multicolumn{2}{|c|}{$\begin{array}{c}\text { Liquid } \\
\text { Assets/Total } \\
\text { Assets }(\%)(+) \\
\end{array}$} & \multicolumn{2}{|c|}{$\begin{array}{c}\text { Liquid } \\
\text { Assets/Total } \\
\text { Foreign } \\
\text { Liabilites }(\%)(+) \\
\end{array}$} & \multicolumn{2}{|c|}{$\begin{array}{l}\text { Gross Loans/ } \\
\text { Deposit }(\%)(-)\end{array}$} & \multicolumn{2}{|c|}{$\begin{array}{c}\text { Customer Deposits/ } \\
\text { Total Funding } \\
(\%)(+) \\
\end{array}$} & \multicolumn{2}{|c|}{$\begin{array}{c}\text { Liquidity Category } \\
\text { Rank }\end{array}$} \\
\hline & $\%$ & Rank & $\%$ & Rank & $\%$ & Rank & $\%$ & Rank & Avg & Rank \\
\hline $\begin{array}{l}\text { Ziraat } \\
\text { Bank }\end{array}$ & $31,56 \%$ & 1 & $96,62 \%$ & 1 & $105,58 \%$ & 1 & $69,00 \%$ & 2 & 1,25 & 1 \\
\hline $\begin{array}{l}\text { Halkb } \\
\text { ank }\end{array}$ & $19,83 \%$ & 5 & $38,40 \%$ & 5 & $123,14 \%$ & 5 & $64,87 \%$ & 5 & 5,00 & 6 \\
\hline $\begin{array}{l}\text { Garan } \\
\text { ti } \\
\text { Bank } \\
\end{array}$ & $22,33 \%$ & 4 & $57,54 \%$ & 4 & $120,20 \%$ & 3 & $65,92 \%$ & 3 & 3,50 & 3 \\
\hline İşbank & $26,66 \%$ & 3 & $74,66 \%$ & 2 & $123,37 \%$ & 6 & $65,58 \%$ & 4 & 3,75 & 4 \\
\hline $\begin{array}{l}\text { Akban } \\
\text { k }\end{array}$ & $30,53 \%$ & 2 & $73,62 \%$ & 3 & $117,24 \%$ & 2 & $62,73 \%$ & 6 & 3,25 & 2 \\
\hline $\begin{array}{l}\text { Şekerb } \\
\text { ank }\end{array}$ & $16,02 \%$ & 6 & $3,84 \%$ & 6 & $122,78 \%$ & 4 & $70,59 \%$ & 1 & 4,25 & 5 \\
\hline
\end{tabular}

Based on Sensitivity category (Table 15), Garanti Bank (2.00) had the top position of average rank followed by Şekerbank(2.67) and İşbank (3.33) and Ziraat Bank and Halkbank with the same average rank of 4.33 stood at the last row.

Table 15. Sensitivity Category Components Ratio and Rank for All Banks (Average of 20142016)

\begin{tabular}{|l|c|c|c|c|c|c|c|c|}
\cline { 2 - 9 } \multicolumn{1}{c|}{} & \multicolumn{2}{c|}{$\begin{array}{c}\text { Securities } \\
\text { Portfolio/Total } \\
\text { Assets(\%)(-) }\end{array}$} & \multicolumn{2}{c|}{$\begin{array}{c}\text { Bearing } \\
\text { Assets/Costly } \\
\text { Liabilities(\%)(+) }\end{array}$} & $\begin{array}{c}\text { Net Interest } \\
\text { Income/Total Assets } \\
(\%)(+)\end{array}$ & $\begin{array}{c}\text { Sensitivity Category } \\
\text { Rank }\end{array}$ \\
\hline Bank & $\%$ & Rank & $\%$ & Rank & $\%$ & Rank & Avg & Rank \\
\hline $\begin{array}{l}\text { Ziraat } \\
\text { Bank }\end{array}$ & $22,88 \%$ & 6 & $100,23 \%$ & 4 & $3,61 \%$ & 3 & 4,33 & 4 \\
\hline Halkbank & $17,14 \%$ & 2 & $98,73 \%$ & 5 & $3,10 \%$ & 6 & 4,33 & 4 \\
\hline $\begin{array}{l}\text { Garanti } \\
\text { Bank }\end{array}$ & $18,76 \%$ & 3 & $106,95 \%$ & 1 & $3,65 \%$ & 2 & 2,00 & 1 \\
\hline Isşbank & $20,23 \%$ & 4 & $105,58 \%$ & 2 & $3,29 \%$ & 4 & 3,33 & 3 \\
\hline Akbank & $22,07 \%$ & 5 & $103,82 \%$ & 3 & $3,12 \%$ & 5 & 4,33 & 4 \\
\hline Şekerbank & $12,01 \%$ & 1 & $98,41 \%$ & 6 & $4,50 \%$ & 1 & 2,67 & 2 \\
\hline
\end{tabular}

From these averages, we see that although the banks are somewhat similar to each other for the categories of capital adequacy, asset quality, sensitivity to market risk, they are not so in terms of management efficiency, earning quality and liquidity categories. 
This is most probably due to the fact that the ratios in the first three categories are the ones that are within the boundaries of prudential rules and standards defined by BRSA.

In order to assess the overall performance rate of this study, we calculated the comprehensive rating and results as presented in the below table (Table 16). It shows that Ziraat Bank (2.77) has the lowest overall average rank and stood at the top position while Halkbank (4.62) has been ranked at the last row.

Table 16. Overall Performance of Each Category for All Banks

\begin{tabular}{|l|c|c|c|c|c|c|c|c|}
\hline \multicolumn{1}{|c|}{ Bank } & C & A & M & E & L & S & Average & Rank \\
\hline Ziraat Bank & 3,25 & 3,60 & 2,00 & 2,20 & 1,25 & 4,33 & 2,77 & 1 \\
\hline Halkbank & 6,00 & 3,80 & 4,17 & 4,40 & 5,00 & 4,33 & 4,62 & 6 \\
\hline Garanti Bank & 1,50 & 3,20 & 3,83 & 3,20 & 3,50 & 2,00 & 2,87 & 2 \\
\hline İşbank & 2,25 & 3,00 & 3,67 & 4,00 & 3,75 & 3,33 & 3,33 & 4 \\
\hline Akbank & 3,00 & 2,40 & 3,00 & 2,80 & 3,25 & 4,33 & 3,13 & 3 \\
\hline Şekerbank & 5,00 & 5,00 & 4,33 & 4,40 & 4,25 & 2,67 & 4,28 & 5 \\
\hline
\end{tabular}

Figure 4 uses the data in Table 16 and shows the average ranks for each category for all six banks.

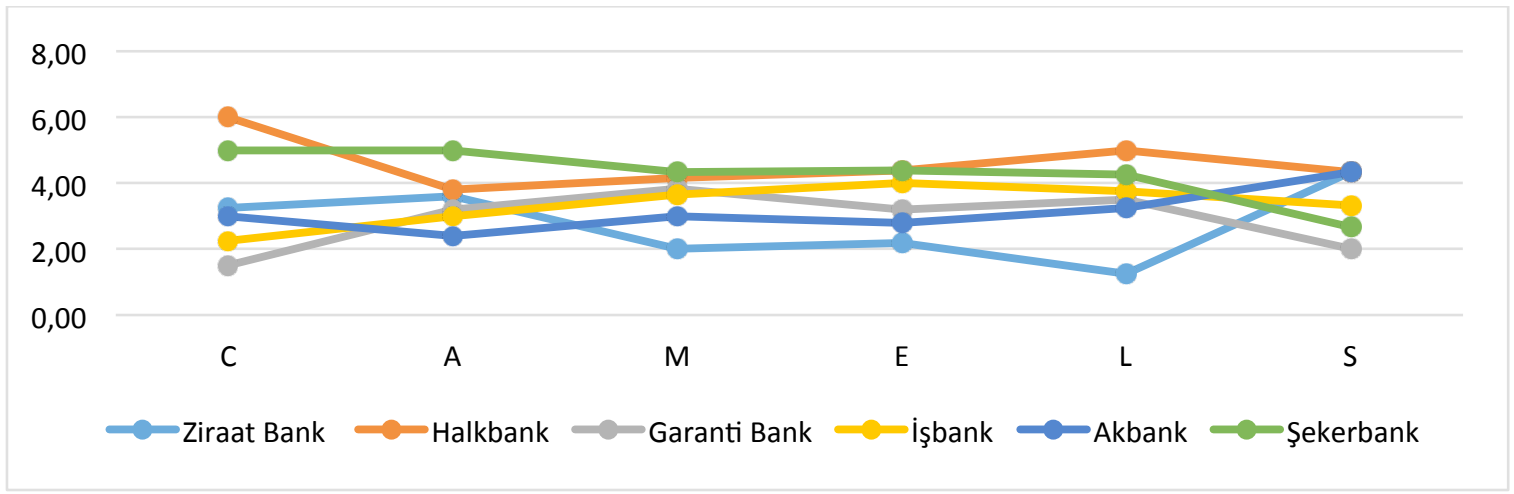

Figure 4. Overall Performance of Each Category for All Banks

\subsection{ANOVA Tests}

We would also like to compare the performance of the banks by implementing ANOVA tests. To determine whether there is a significant difference between the means of CAMELS ratios, for the 2014-16 period, we applied one-way ANOVA test on the data shown in table 16. The results of one-way ANOVA test are presented in table 17. The null hypothesis expresses that the average ranks for all categories for a bank are equal. The p-value is compared to the significance level to assess the null hypothesis. The "p-value" for this test was 0.00218 which is less than the significance level (0.05). It means that we reject the null hypothesis. So we conclude that there is a statistically significant difference between the means of CAMELS categories. 
Table 17. One-way ANOVA Test for Six Categories of CAMELS

\begin{tabular}{|c|c|c|c|c|c|c|}
\hline $\begin{array}{l}\text { Source of } \\
\text { Variation }\end{array}$ & $S S$ & $d f$ & $M S$ & $F$ & $P$-value & $F$ crit \\
\hline Between Groups & 17,61361111 & 5 & 3,522722222 & 4,884817359 & 0,002184785 & 2,53355 \\
\hline Within Groups & 21,63472222 & 30 & 0,721157407 & & & \\
\hline Total & 39,24833333 & 35 & & & & \\
\hline
\end{tabular}

To determine whether there is a significant difference between the means of CAMELS ratios during twelve years of the study, we applied one-way ANOVA test on the data shown in Table $7^{1}$. The results of one-way ANOVA test are presented in table 18. The null hypothesis express that the means of CAMELS ratios for the banks are equal to each other for the period. The $\mathrm{p}$-value is compared to the significance level to assess the null hypothesis. The "p-value" for this test is significant, thus we reject the null hypothesis. So it means that there is a statistically significant difference between the means of CAMELS ratios of the banks during twelve years of this study.

Table 18. One-way ANOVA Test for Overall Rates during 12 Years

ANOVA: Single Factor

\begin{tabular}{lcccccc}
\hline $\begin{array}{l}\text { Source of } \\
\text { Variation }\end{array}$ & $S S$ & $d f$ & $M S$ & $F$ & P-value & F crit \\
\hline Between & & & & & & \\
Groups & 0,114629088 & 5 & 0,022925818 & 6,583031849 & $5,01878 \mathrm{E}-05$ & 2,353808958 \\
Within & & & & & & \\
Groups & 0,229849103 & 66 & 0,003482562 & & & \\
Total & 0,344478192 & 71 & & & & \\
\hline
\end{tabular}

\subsection{Comparison of CAMELS ratings with the international agency ratings}

CAMELS Rating system is a method used as an early warning mechanism about the credibility of a bank from the very early years of banking regulation history. In this part of the study, we would like to compare the outcomes of custom-made CAMELS rating system with the ratings provided by international rating agencies to see whether "through the cycle" ratings can catch up with the changes observed with "point in time" CAMELS rating system. Table 19 shows the selected ratios for each category. Based on some ranges, each ratio lies on a rating from 1 to 5 . Rating 1 is the best score and rating of 5 is the worst. Table 20 and 21 exhibits the calculated ratios and ratings for the sample. Table 22 presents the comparison of ratings prepared by international rating

\footnotetext{
${ }^{1}$ These two ANOVA tests are quite different in terms of data used. In the first ANOVA test, the data is the average ranks for the C, A, M, E, L and S values over the last three years. However, the second ANOVA test uses overall CAMELS ratios (not the ranks) for six banks for the twelve years analyzed (2005-2016). This is the first study, to our knowledge, to be able to make such an ANOVA analysis, since we have the sufficient number of years to be analyzed.
} 
agencies with the output of our own CAMELS ratings for respective banks from 2005 to 2016. S\&P and JCR Eurasia have a quite limited number of ratings and these ratings do not change much during the period for the banks in concern. Thus, we will focus on Moody's and Fitch ratings in this study. The ratings of these two rating companies and CAMELS ratings have all different scales $^{2}$ thus the comparison will not be done on one by one basis but in terms of rankings and changes in the rankings over the years. What we can precisely conclude is that in 2005, the priority rank is for Ziraat Bank which stands first and Akbank is the second in row while Şekerbank is the last one in the rate ranking based on CAMELS rating. Exactly the same ranking for the selected banks has been provided by Fitch. Fitch ranting ranked banks from the best to worst respectively as follows: Ziraat Bank (A), Akbank (BB+), İşbank (BB), Garanti Bank and Halkbank with the same rate of BB- stand in the same row and Şekerbank (B-) stands at last row. However, Moody's rating ranked banks from the best to worst respectively as follows: Akbank and İşbank with the same rank (A3) are at the top, Ziraat Bank and Garanti Bank with the same rank stand at second row but by a difference of three categories (B1). It is important that this ranking does not really reflect the very close CAMELS values of İşbank and Ziraatbank. Moody's did not even rate the other two banks for that year.

After looking at the rankings for the first year of this study (2005), it is worth to check the results for the last year of the study (2016). What we can observe is that the priority rank for 2016 does not change according to computed CAMELS ratings as Ziraat Bank stands first and Akbank is the second in the row while Şekerbank is the last one again. Moody's ranked banks in a way that Şekerbank (Baa2) has the highest rate and the rest of the banks have a rate of Ba1. Thus all of the banks carry substantial credit risk except Şekerbank which on the other hand carries moderate credit risk. Fitch has ranked banks from the best to worst respectively as follows: Garanti Bank and Halkbank with the same rate of (BBB), Ziraat Bank (BBB-), İşbank and Akbank with the same rate of $(\mathrm{BB}+)$ and Şekerbank with rate of (BB-). For Fitch, some of the banks, namely Ziraatbank, Garanti, and Halkbank still have low default risks but the other three banks are under a speculative category. The rankings are not really consistent with CAMELS ratings. But when we look at the ratings closely, it is seen that both the institutional ratings and CAMELS ratings are very close to each other for all the banks.

Looking at what happened during the twelve-year period is more interesting. First, let's see the trend in Moody's ratings. This trend may be taken as one proof for the through the cyclical nature of the institutional ratings. For Ziraatbank, for example, Moody's corrects its rating from B1 to Baal only in 2007 after observing superior CAMELS ratings for consecutive three years (maybe more). For Garanti, Akbank, and İşbank, that correction comes quite late only in 2009. Moody's ratings for these three banks are A3 (strong, low risk) which is higher than the rating for Ziraatbank and only becomes Baa1/2/3 in 2009. On the other hand in these years CAMELS ratings for these banks oscillate between 2.00 and 2.70 and are worse than the ratings of Ziraatbank. Moody's starts to rate Şekerbank only in 2012. Şekerbank's rating is increased to be A3 for no apparent reason at all in 2014 and 2015 and then is normalized somewhat in 2016.

\footnotetext{
${ }^{2}$ The definitions of the scales can be found in Appendix 1.
} 
Fitch ratings are more consistent with the CAMELS ratings than the Moody's ratings. For the period, Ziraatbank starts with A rating (where CAMELS rating also shows strong and low-risk status) then gradually decrease to BB and BBB in 2015 as the CAMELS ratings also deteriorate. For the last five years, there is no difference in the CAMELS ratings of four banks, namely Garanti, Akbank, İşbank, and Halkbank. Similarly, Fitch ratings are also quite close for these years. Only Şekerbank has clearly worse CAMELS and Fitch ratings compared to others for these years. Overall, Şekerbank's Fitch rating changes from "Highly speculative" to "Speculative" category over the twelve-year period although there is no improvement in CAMELS rating. This can be attributed to the argument that if one risky company survives; its probability of surviving would increase over time. Overall, we can conclude that ratings of institutions do lag the financial indicators of the companies and even can be not reflective of the current financial condition of the company. But the trend of the ratings and rankings of financial indicators are consistent over a long period of time.

Table 19. Evaluation under CAMELS rating system

\begin{tabular}{|c|c|c|c|c|c|c|c|c|}
\hline & Component & Ratio & Weight & Rating 1 & Rating 2 & Rating 3 & Rating 4 & Rating 5 \\
\hline $\mathrm{C}$ & $\begin{array}{l}\text { Capital } \\
\text { Adequacy }\end{array}$ & $\begin{array}{l}\text { Capital Adequacy } \\
\text { Ratio }\end{array}$ & $20 \%$ & $\geq 15 \%$ & $12 \%-14,99 \%$ & $8 \%-11,99 \%$ & $7 \%-7,99 \%$ & $\leq 6,99 \%$ \\
\hline A & Asset Quality & $\begin{array}{l}\text { (NPLs-Specific } \\
\text { Provision } \\
\text { Reserve)/Gross } \\
\text { Loans }\end{array}$ & $20 \%$ & $\leq 1,25 \%$ & $\leq 2,59 \%-1,26 \%$ & $\leq 3,5 \%-2,6 \%$ & $\leq 5,5 \%-3,6 \%$ & $\geq 5,6 \%$ \\
\hline M & Management & $\begin{array}{l}\text { Non-Interest Exp./ } \\
\text { Net Interest Inc.+ } \\
\text { Non-Interest Inc. } \\
(\%)(-)\end{array}$ & $25 \%$ & $\leq 25 \%$ & $26 \%-30,99 \%$ & $31 \%-38,90 \%$ & $39 \%-45,90 \%$ & $\geq 46 \%$ \\
\hline \multirow{2}{*}{$\mathrm{E}$} & $\begin{array}{l}\text { Earnings } \\
\text { (ROA) }\end{array}$ & $\begin{array}{l}\text { Net Income/Total } \\
\text { Assets }\end{array}$ & \multirow{2}{*}{$15 \%$} & $\geq 1 \%$ & $0,8 \%-0,9 \%$ & $0,35 \%-0,7 \%$ & $0,25 \%-0,34 \%$ & $\leq 0,24 \%$ \\
\hline & $\begin{array}{l}\text { Earnings } \\
\text { (ROE) }\end{array}$ & Net Income/Equity & & $\geq 22 \%$ & $17 \%-21,99 \%$ & $10 \%-16,99 \%$ & $7 \%-9,99 \%$ & $\leq 6,99 \%$ \\
\hline \multirow{2}{*}{$\mathrm{L}$} & Liquidity(L1) & $\begin{array}{l}\text { Gross Loans/ } \\
\text { Deposit }\end{array}$ & \multirow{2}{*}{$10 \%$} & $\leq 55 \%$ & $55,01 \%-62 \%$ & $63 \%-68 \%$ & $69 \%-80,99 \%$ & $\geq 81 \%$ \\
\hline & Liquidity(L2) & $\begin{array}{l}\text { Liquid Assets/Total } \\
\text { Assets }\end{array}$ & & $\geq 50 \%$ & $45 \%-49,99 \%$ & $38 \%-44,99 \%$ & $\begin{array}{l}32,01 \%- \\
37,99 \%\end{array}$ & $\leq 32 \%$ \\
\hline $\mathrm{S}$ & Sensitivity & $\begin{array}{l}\text { Securities } \\
\text { Portfolio/Total } \\
\text { Assets }\end{array}$ & $10 \%$ & $\leq 25,49 \%$ & $25,50 \%-30,99 \%$ & $31 \%-37,99 \%$ & $38 \%-42,99 \%$ & $\geq 43 \%$ \\
\hline
\end{tabular}

Source: CAMELS Rating System for Banking Industry in Pakistan, (Babar \& Lions, 2011) Page 54 
M. Ghazavi - S. Bayraktar 10/2 (2018) 847-874

Table 20. CAMELS Rating Applied to Sample Banks (2005-2010)

\begin{tabular}{|c|c|c|c|c|c|c|c|c|c|c|c|c|c|c|c|c|}
\hline \multirow[b]{3}{*}{ Bank } & \multicolumn{14}{|c|}{2005} & & \\
\hline & \multicolumn{2}{|c|}{ Capital Adequacy } & \multicolumn{2}{|c|}{ Asset Quality Ratio } & \multicolumn{2}{|c|}{ Management Quality } & \multicolumn{4}{|c|}{ Earning Efficiency } & \multicolumn{4}{|c|}{ Liquidity } & \multicolumn{2}{|c|}{ Sensitivity to market risk } \\
\hline & CAR & Rating & $\mathrm{AQR}$ & Rating & MQR & Rating & EE1 & Rating & EE2 & Rating & L1 & Rating & L2 & Rating & Sens. & Rating \\
\hline Ziraatbank & $47,88 \%$ & 1 & $0,39 \%$ & 1 & $30,31 \%$ & 2 & $2,87 \%$ & 1 & $17,13 \%$ & 2 & $26,95 \%$ & 1 & $40,78 \%$ & 3 & $60,80 \%$ & 5 \\
\hline Garanti bank & $15,10 \%$ & 1 & $1,33 \%$ & 2 & $48,36 \%$ & 5 & $1,98 \%$ & 1 & $18,78 \%$ & 2 & $80,31 \%$ & 4 & $38,10 \%$ & 3 & $33,13 \%$ & 3 \\
\hline \begin{tabular}{|l|l} 
Akbank \\
\end{tabular} & $21,43 \%$ & 1 & $0,00 \%$ & 1 & $35,10 \%$ & 3 & $2,80 \%$ & 1 & $23,07 \%$ & 1 & $78,16 \%$ & 4 & $41,65 \%$ & 3 & $42,91 \%$ & 4 \\
\hline İşbank & $25,00 \%$ & 1 & $0,00 \%$ & 1 & $44,10 \%$ & 4 & $1,82 \%$ & 1 & $12,51 \%$ & 3 & $65,91 \%$ & 3 & $52,00 \%$ & 1 & $42,54 \%$ & 4 \\
\hline Halkbank & $49,64 \%$ & 1 & $0,26 \%$ & 1 & $42,42 \%$ & 4 & $2,06 \%$ & 1 & $16,79 \%$ & 3 & $35,79 \%$ & 1 & $14,62 \%$ & 5 & $65,76 \%$ & 5 \\
\hline Seker bank & $20,23 \%$ & 1 & $0,00 \%$ & 1 & $56,41 \%$ & 5 & $1,08 \%$ & 1 & $9,12 \%$ & 4 & $55,62 \%$ & 2 & $38,95 \%$ & 3 & $43,21 \%$ & 5 \\
\hline
\end{tabular}

\begin{tabular}{|c|c|c|c|c|c|c|c|c|c|c|c|c|c|c|c|c|}
\hline \multirow[b]{3}{*}{ Bank } & \multicolumn{14}{|c|}{2006} & & \\
\hline & \multicolumn{2}{|c|}{\begin{tabular}{|l|} 
Capital Adequacy \\
\end{tabular}} & \multicolumn{2}{|c|}{\begin{tabular}{|l|} 
Asset Quality Ratio \\
\end{tabular}} & \multicolumn{2}{|c|}{ Management Quality } & \multicolumn{4}{|c|}{ Earning Efficiency } & \multicolumn{4}{|c|}{ Liquidity } & \multicolumn{2}{|c|}{ Sensitivity to market risk } \\
\hline & CAR & Rating & $\mathrm{AQR}$ & Rating & MQR & Rating & EE1 & Rating & EE2 & Rating & L1 & Rating & L2 & Rating & Sens. & Rating \\
\hline Ziraatbank & $39,55 \%$ & 1 & $0,35 \%$ & 1 & $32,26 \%$ & 3 & $2,92 \%$ & 1 & $31,92 \%$ & 1 & $29,78 \%$ & 1 & $46,51 \%$ & 2 & $61,55 \%$ & 5 \\
\hline Garanti bank & $14,10 \%$ & 2 & $0,66 \%$ & 1 & $46,96 \%$ & 5 & $2,12 \%$ & 1 & $22,78 \%$ & 1 & $96,09 \%$ & 5 & $31,42 \%$ & 5 & $29,80 \%$ & 2 \\
\hline Akbank & $20,67 \%$ & 1 & $0,00 \%$ & 1 & $39,98 \%$ & 4 & $2,79 \%$ & 1 & $22,65 \%$ & 1 & $89,11 \%$ & 5 & $35,75 \%$ & 4 & $37,08 \%$ & 3 \\
\hline İşbank & $23,90 \%$ & 1 & $0,00 \%$ & 1 & $42,25 \%$ & 4 & $1,47 \%$ & 1 & $11,79 \%$ & 3 & $70,07 \%$ & 4 & $50,62 \%$ & 1 & $41,24 \%$ & 4 \\
\hline Halkbank & $31,95 \%$ & 1 & $0,12 \%$ & 1 & $35,41 \%$ & 3 & $2,51 \%$ & 1 & $22,84 \%$ & 1 & $48,37 \%$ & 1 & $28,30 \%$ & 5 & $53,08 \%$ & 5 \\
\hline Seker bank & $16,74 \%$ & 1 & $0,00 \%$ & 1 & $53,24 \%$ & 5 & $1,30 \%$ & 1 & $11,90 \%$ & 3 & $73,89 \%$ & 4 & $35,24 \%$ & 4 & $30,72 \%$ & 2 \\
\hline
\end{tabular}

\begin{tabular}{|c|c|c|c|c|c|c|c|c|c|c|c|c|c|c|c|c|}
\hline \multirow[b]{3}{*}{ Bank } & \multicolumn{16}{|c|}{2007} \\
\hline & \multicolumn{2}{|c|}{ Capital Adequacy } & \multicolumn{2}{|c|}{ Asset Quality Ratio } & \multicolumn{2}{|c|}{ Management Quality } & \multicolumn{4}{|c|}{ Earning Efficiency } & \multicolumn{4}{|c|}{ Liquidity } & \multicolumn{2}{|c|}{ Sensitivity to market risk } \\
\hline & CAR & Rating & $\mathrm{AQR}$ & Rating & MQR & Rating & EE1 & Rating & EE2 & Rating & L1 & Rating & L2 & Rating & Sens. & Rating \\
\hline Ziraatbank & $25,44 \%$ & 1 & $0,36 \%$ & 1 & $31,73 \%$ & 3 & $2,90 \%$ & 1 & $32,57 \%$ & 1 & $32,49 \%$ & 1 & $53,28 \%$ & 1 & $58,00 \%$ & 5 \\
\hline Garanti bank & $15,40 \%$ & 1 & $0,81 \%$ & 1 & $36,96 \%$ & 3 & $3,43 \%$ & 1 & $33,64 \%$ & 1 & $101,48 \%$ & 5 & $34,70 \%$ & 4 & $26,24 \%$ & 2 \\
\hline Akbank & $18,91 \%$ & 1 & $0,00 \%$ & 1 & $34,78 \%$ & 3 & $2,92 \%$ & 1 & $18,81 \%$ & 2 & $97,23 \%$ & 5 & $35,66 \%$ & 4 & $37,83 \%$ & 3 \\
\hline Isşbank & $20,50 \%$ & 1 & $0,00 \%$ & 1 & $36,67 \%$ & 3 & $2,12 \%$ & 1 & $16,05 \%$ & 3 & $74,24 \%$ & 4 & \begin{tabular}{|l|}
$44,67 \%$ \\
\end{tabular} & 3 & $36,35 \%$ & 3 \\
\hline Halkbank & $20,03 \%$ & 1 & $0,07 \%$ & 1 & $34,22 \%$ & 3 & $2,81 \%$ & 1 & $25,80 \%$ & 1 & $64,29 \%$ & 3 & $32,58 \%$ & 4 & $40,47 \%$ & 4 \\
\hline Şeker bank & $16,84 \%$ & 1 & $0,00 \%$ & 1 & $49,43 \%$ & 5 & $2,02 \%$ & 1 & $14,21 \%$ & 3 & $95,49 \%$ & 5 & $29,55 \%$ & 5 & $22,93 \%$ & 1 \\
\hline
\end{tabular}

\begin{tabular}{|c|c|c|c|c|c|c|c|c|c|c|c|c|c|c|c|c|}
\hline \multirow[b]{3}{*}{ Bank } & \multicolumn{14}{|c|}{2008} & \multirow{2}{*}{\multicolumn{2}{|c|}{ Sensitivity to market risk }} \\
\hline & \multicolumn{2}{|c|}{\begin{tabular}{|l|} 
Capital Adequacy \\
\end{tabular}} & \multicolumn{2}{|c|}{ Asset Quality Ratio } & \multicolumn{2}{|c|}{ Management Quality } & \multicolumn{4}{|c|}{ Earning Efficiency } & \multicolumn{4}{|c|}{ Liquidity } & & \\
\hline & CAR & Rating & $\mathrm{AQR}$ & Rating & MQR & Rating & EE1 & Rating & EE2 & Rating & L1 & Rating & L2 & Rating & Sens. & Rating \\
\hline Ziraatbank & $20,08 \%$ & 1 & $0,36 \%$ & 1 & $34,59 \%$ & 3 & $2,04 \%$ & 1 & $28,99 \%$ & 1 & $38,05 \%$ & 1 & $21,22 \%$ & 5 & $56,68 \%$ & 5 \\
\hline Garanti bank & $16,10 \%$ & 1 & $0,88 \%$ & 1 & $48,24 \%$ & 5 & $1,97 \%$ & 1 & $18,49 \%$ & 2 & $100,19 \%$ & 5 & $31,17 \%$ & 5 & $29,05 \%$ & 2 \\
\hline \begin{tabular}{|l|} 
Akbank \\
\end{tabular} & $18,20 \%$ & 1 & $0,00 \%$ & 1 & $40,54 \%$ & 4 & $1,99 \%$ & 1 & $15,21 \%$ & 3 & $94,16 \%$ & 5 & $21,10 \%$ & 5 & $32,59 \%$ & 3 \\
\hline İşbank & $15,20 \%$ & 1 & $0,00 \%$ & 1 & $45,25 \%$ & 4 & $1,55 \%$ & 1 & $15,97 \%$ & 3 & $80,14 \%$ & 4 & $40,88 \%$ & 3 & $28,78 \%$ & 2 \\
\hline Halkbank & $14,49 \%$ & 2 & $0,79 \%$ & 1 & $37,05 \%$ & 3 & $1,99 \%$ & 1 & $23,74 \%$ & 1 & $69,44 \%$ & 4 & $14,66 \%$ & 5 & $36,36 \%$ & 3 \\
\hline Șeker bank & $14,70 \%$ & 2 & $1,70 \%$ & 2 & $54,98 \%$ & 5 & $1,79 \%$ & 1 & $14,80 \%$ & 3 & $86,21 \%$ & 5 & $17,05 \%$ & 5 & $28,42 \%$ & 2 \\
\hline
\end{tabular}

\begin{tabular}{|c|c|c|c|c|c|c|c|c|c|c|c|c|c|c|c|c|}
\hline \multirow{3}{*}{ Bank } & \multicolumn{14}{|c|}{2009} & \multirow{2}{*}{\multicolumn{2}{|c|}{ Sensitivity to market risl }} \\
\hline & \multicolumn{2}{|c|}{\begin{tabular}{|l|} 
Capital Adequacy \\
\end{tabular}} & \multicolumn{2}{|c|}{\begin{tabular}{|l|} 
Asset Quality Ratio \\
\end{tabular}} & \multicolumn{2}{|c|}{ Management Quality } & \multicolumn{4}{|c|}{ Earning Efficiency } & \multicolumn{4}{|c|}{ Liquidity } & & \\
\hline & CAR & Rating & $\mathrm{AQR}$ & Rating & MQR & Rating & EE1 & Rating & EE2 & Rating & L1 & Rating & L2 & Rating & Sens. & Rating \\
\hline Ziraatbank & $23,22 \%$ & 1 & $0,46 \%$ & 1 & $27,29 \%$ & 2 & $2,82 \%$ & 1 & $33,91 \%$ & 1 & $38,37 \%$ & 1 & $32,32 \%$ & 4 & $57,58 \%$ & 5 \\
\hline Garanti bank & $21,20 \%$ & 1 & $0,82 \%$ & 1 & $33,36 \%$ & 3 & $2,81 \%$ & 1 & $22,25 \%$ & 1 & $85,93 \%$ & 5 & $42,00 \%$ & 3 & $34,91 \%$ & 3 \\
\hline \begin{tabular}{|l|} 
Akbank \\
\end{tabular} & $22,50 \%$ & 1 & $0,00 \%$ & 1 & $33,11 \%$ & 3 & $2,86 \%$ & 1 & $19,21 \%$ & 2 & $79,37 \%$ & 4 & $38,68 \%$ & 3 & $48,35 \%$ & 5 \\
\hline İşbank & $18,30 \%$ & 1 & $0,00 \%$ & 1 & $33,99 \%$ & 3 & $2,10 \%$ & 1 & $17,58 \%$ & 2 & $72,67 \%$ & 4 & $38,13 \%$ & 3 & $39,14 \%$ & 4 \\
\hline Halkbank & $16,03 \%$ & 1 & $0,91 \%$ & 1 & $30,95 \%$ & 2 & $2,69 \%$ & 1 & $28,32 \%$ & 1 & $81,20 \%$ & 5 & $15,35 \%$ & 5 & $35,77 \%$ & 3 \\
\hline \begin{tabular}{|l} 
Șeker bank \\
\end{tabular} & $16,30 \%$ & 1 & $1,96 \%$ & 2 & $49,57 \%$ & 5 & $1,70 \%$ & 1 & $12,20 \%$ & 3 & $80,21 \%$ & 4 & $17,38 \%$ & 5 & $34,62 \%$ & 3 \\
\hline
\end{tabular}

\begin{tabular}{|c|c|c|c|c|c|c|c|c|c|c|c|c|c|c|c|c|}
\hline \multirow[b]{3}{*}{ Bank } & \multicolumn{16}{|c|}{2010} \\
\hline & \multicolumn{2}{|c|}{\begin{tabular}{|l|} 
Capital Adequacy \\
\end{tabular}} & \multicolumn{2}{|c|}{ Asset Quality Ratio } & \multicolumn{2}{|c|}{ Management Quality } & \multicolumn{4}{|c|}{ Earning Efficiency } & \multicolumn{4}{|c|}{ Liquidity } & \multicolumn{2}{|c|}{ Sensitivity to market risk } \\
\hline & CAR & Rating & $\mathrm{AQR}$ & Rating & MQR & Rating & EE1 & Rating & EE2 & Rating & L1 & Rating & L2 & Rating & Sens. & Rating \\
\hline Ziraatbank & $19,20 \%$ & 1 & $0,48 \%$ & 1 & $32,78 \%$ & 3 & $2,46 \%$ & 1 & $27,59 \%$ & 1 & $47,27 \%$ & 1 & $36,14 \%$ & 4 & $50,98 \%$ & 5 \\
\hline Garanti bank & $19,60 \%$ & 1 & $0,53 \%$ & 1 & $40,13 \%$ & 4 & $2,54 \%$ & 1 & $19,09 \%$ & 2 & $95,04 \%$ & 5 & $38,86 \%$ & 3 & $32,67 \%$ & 3 \\
\hline \begin{tabular}{|l|} 
Akbank \\
\end{tabular} & $20,61 \%$ & 1 & $0,00 \%$ & 1 & $37,13 \%$ & 3 & $2,52 \%$ & 1 & $16,26 \%$ & 3 & $90,61 \%$ & 5 & $44,27 \%$ & 3 & $44,45 \%$ & 5 \\
\hline İșbank & $17,50 \%$ & 1 & $0,00 \%$ & 1 & $40,59 \%$ & 4 & $2,26 \%$ & 1 & $17,53 \%$ & 2 & $77,68 \%$ & 4 & $32,68 \%$ & 4 & $39,23 \%$ & 4 \\
\hline \begin{tabular}{|l|} 
Halkbank \\
\end{tabular} & $15,94 \%$ & 1 & $0,64 \%$ & 1 & $33,50 \%$ & 3 & $2,76 \%$ & 1 & $27,00 \%$ & 1 & $89,32 \%$ & 5 & $18,04 \%$ & 5 & $28,72 \%$ & 2 \\
\hline Şeker bank & $14,01 \%$ & 2 & $1,59 \%$ & 2 & $57,63 \%$ & 5 & $1,50 \%$ & 1 & $12,16 \%$ & 3 & $98,62 \%$ & 5 & $20,17 \%$ & 5 & $27,42 \%$ & 2 \\
\hline
\end{tabular}


M. Ghazavi - S. Bayraktar 10/2 (2018) 847-874

Table 21. CAMELS Rating Applied to Sample Banks (2011-2016)

\begin{tabular}{|c|c|c|c|c|c|c|c|c|c|c|c|c|c|c|c|c|}
\hline \multirow[b]{3}{*}{ Bank } & \multicolumn{14}{|c|}{2011} & \multirow{2}{*}{\multicolumn{2}{|c|}{ Sensitivity to market risk }} \\
\hline & \multicolumn{2}{|c|}{\begin{tabular}{|l|} 
Capital Adequacy \\
\end{tabular}} & \multicolumn{2}{|c|}{ Asset Quality Ratio } & \multicolumn{2}{|c|}{ Management Quality } & \multicolumn{4}{|c|}{ Earning Efficiency } & \multicolumn{4}{|c|}{ Liquidity } & & \\
\hline & CAR & Rating & $\mathrm{AQR}$ & Rating & $\mathrm{MQR}$ & Rating & EE1 & Rating & EE2 & Rating & L1 & Rating & L2 & Rating & Sens. & Rating \\
\hline Ziraatbank & $15,61 \%$ & 1 & $0,36 \%$ & 1 & $42,23 \%$ & 4 & $1,31 \%$ & 1 & $15,94 \%$ & 3 & $65,69 \%$ & 3 & $33,43 \%$ & 4 & $44,50 \%$ & 5 \\
\hline Garanti bank & $16,90 \%$ & 1 & $0,33 \%$ & 1 & $40,40 \%$ & 4 & $2,09 \%$ & 1 & $17,47 \%$ & 2 & $103,03 \%$ & 5 & $35,05 \%$ & 4 & $25,08 \%$ & 1 \\
\hline Akbank & $16,98 \%$ & 1 & $0,13 \%$ & 1 & $40,01 \%$ & 4 & $1,79 \%$ & 1 & $13,64 \%$ & 3 & $107,42 \%$ & 5 & $40,86 \%$ & 3 & $32,83 \%$ & 3 \\
\hline İsbank & $14,10 \%$ & 2 & $0,00 \%$ & 1 & $42,64 \%$ & 4 & $1,65 \%$ & 1 & $14,88 \%$ & 3 & $97,44 \%$ & 5 & $27,64 \%$ & 5 & $30,34 \%$ & 2 \\
\hline Halkbank & $14,30 \%$ & 2 & $0,46 \%$ & 1 & $34,15 \%$ & 3 & $2,24 \%$ & 1 & $23,67 \%$ & 1 & $97,22 \%$ & 5 & $19,72 \%$ & 5 & $26,64 \%$ & 2 \\
\hline \begin{tabular}{|l} 
Seker bank \\
\end{tabular} & $13,24 \%$ & 2 & $2,59 \%$ & 2 & $62,32 \%$ & 5 & $0,82 \%$ & 2 & $8,07 \%$ & 4 & $98,12 \%$ & 5 & $30,37 \%$ & 5 & $26,85 \%$ & 2 \\
\hline
\end{tabular}

\begin{tabular}{|c|c|c|c|c|c|c|c|c|c|c|c|c|c|c|c|c|}
\hline \multirow[b]{3}{*}{ Bank } & \multicolumn{14}{|c|}{2012} & \multirow{2}{*}{\multicolumn{2}{|c|}{ Sensitivity to market risk }} \\
\hline & \multicolumn{2}{|c|}{ Capital Adequacy } & \multicolumn{2}{|c|}{\begin{tabular}{|l} 
Asset Quality Ratio \\
\end{tabular}} & \multicolumn{2}{|c|}{ Management Quality } & \multicolumn{4}{|c|}{ Earning Efficiency } & \multicolumn{4}{|c|}{ Liquidity } & & \\
\hline & CAR & Rating & $\mathrm{AQR}$ & Rating & MQR & Rating & EE1 & Rating & EE2 & Rating & L1 & Rating & L2 & Rating & Sens. & Rating \\
\hline Ziraatbank & \begin{tabular}{|l|}
$19,01 \%$ \\
\end{tabular} & 1 & $1,10 \%$ & 1 & $34,80 \%$ & 3 & $1,63 \%$ & 1 & $15,44 \%$ & 3 & $65,07 \%$ & 3 & $37,28 \%$ & 4 & $40,75 \%$ & 4 \\
\hline Garanti bank & $18,20 \%$ & 1 & $0,43 \%$ & 1 & $40,97 \%$ & 4 & $1,92 \%$ & 1 & $14,41 \%$ & 3 & $111,78 \%$ & 5 & $37,29 \%$ & 4 & $25,27 \%$ & 1 \\
\hline \begin{tabular}{|l|} 
Akbank \\
\end{tabular} & $18,63 \%$ & 1 & $0,10 \%$ & 1 & $37,11 \%$ & 3 & $1,89 \%$ & 1 & $13,46 \%$ & 3 & $117,68 \%$ & 5 & $39,32 \%$ & 3 & $29,62 \%$ & 2 \\
\hline Isşbank & $16,30 \%$ & 1 & $0,39 \%$ & 1 & $45,69 \%$ & 4 & $1,89 \%$ & 1 & $14,57 \%$ & 3 & $106,26 \%$ & 5 & $24,93 \%$ & 5 & $26,08 \%$ & 2 \\
\hline Halkbank & $16,17 \%$ & 1 & $0,51 \%$ & 1 & $33,23 \%$ & 3 & $2,40 \%$ & 1 & $21,06 \%$ & 2 & $93,06 \%$ & 5 & $22,64 \%$ & 5 & $22,94 \%$ & 1 \\
\hline \begin{tabular}{|l} 
Șeker bank \\
\end{tabular} & $14,48 \%$ & 2 & $1,50 \%$ & 2 & $48,90 \%$ & 5 & $1,66 \%$ & 1 & $13,17 \%$ & 3 & $104,36 \%$ & 5 & $18,54 \%$ & 5 & $15,49 \%$ & 1 \\
\hline
\end{tabular}

\begin{tabular}{|c|c|c|c|c|c|c|c|c|c|c|c|c|c|c|c|c|}
\hline \multirow[b]{3}{*}{ Bank } & \multirow{2}{*}{\multicolumn{2}{|c|}{$\begin{array}{l}\text { Capital Adequacy } \\
\end{array}$}} & & & & & & 20 & 13 & & & & & & & \\
\hline & & & \multicolumn{2}{|c|}{ Asset Quality Ratio } & \multicolumn{2}{|c|}{ Management Quality } & \multicolumn{4}{|c|}{ Earning Efficiency } & \multicolumn{4}{|c|}{ Liquidity } & \multicolumn{2}{|c|}{ Sensitivity to market risk } \\
\hline & CAR & Rating & $\mathrm{AQR}$ & Rating & $\mathrm{MQR}$ & Rating & EE1 & Rating & EE2 & Rating & L1 & Rating & L2 & Rating & Sens. & Rating \\
\hline Ziraatbank & $13,21 \%$ & 2 & $0,71 \%$ & 1 & $37,10 \%$ & 3 & $1,60 \%$ & 1 & $18,13 \%$ & 2 & $84,34 \%$ & 5 & $36,50 \%$ & 4 & $30,67 \%$ & 2 \\
\hline \begin{tabular}{|l|} 
Garanti bank \\
\end{tabular} & $14,40 \%$ & 2 & $0,40 \%$ & 1 & $43,00 \%$ & 4 & $1,53 \%$ & 1 & $13,31 \%$ & 3 & $118,86 \%$ & 5 & $27,48 \%$ & 5 & $20,05 \%$ & 1 \\
\hline \begin{tabular}{|l|} 
Akbank \\
\end{tabular} & $14,95 \%$ & 2 & $0,08 \%$ & 1 & $37,46 \%$ & 3 & $1,60 \%$ & 1 & $13,79 \%$ & 3 & $119,65 \%$ & 5 & $30,27 \%$ & 5 & $24,79 \%$ & 1 \\
\hline Isşbank & $14,40 \%$ & 2 & $0,32 \%$ & 1 & $48,24 \%$ & 5 & $1,50 \%$ & 1 & $13,42 \%$ & 3 & $117,17 \%$ & 5 & $25,13 \%$ & 5 & $21,20 \%$ & 1 \\
\hline Halkbank & $13,91 \%$ & 2 & $0,50 \%$ & 1 & $38,65 \%$ & 3 & $1,97 \%$ & 1 & $19,45 \%$ & 2 & $95,50 \%$ & 5 & $22,41 \%$ & 5 & $22,14 \%$ & 1 \\
\hline \begin{tabular}{|l} 
SSeker bank \\
\end{tabular} & $13,54 \%$ & 2 & $2,34 \%$ & 2 & $59,58 \%$ & 5 & $1,12 \%$ & 1 & $10,23 \%$ & 3 & $116,31 \%$ & 5 & $15,71 \%$ & 5 & $9,86 \%$ & 1 \\
\hline
\end{tabular}

\begin{tabular}{|c|c|c|c|c|c|c|c|c|c|c|c|c|c|c|c|c|}
\hline \multirow[b]{3}{*}{ Bank } & \multicolumn{14}{|c|}{2014} & & \\
\hline & Capital & dequacy & Asset Qu: & ity Ratio & Manage & th Quality & & Earning & Efficien & & & Liqui & & & \multicolumn{2}{|c|}{ Sensitivity to market risk } \\
\hline & CAR & Rating & $\mathrm{AQR}$ & Rating & MQR & Rating & EE1 & Rating & EE2 & Rating & L1 & Rating & L2 & Rating & Sens. & Rating \\
\hline Ziraatbank & $18,22 \%$ & 1 & $0,55 \%$ & 1 & $38,21 \%$ & 3 & $1,64 \%$ & 1 & $14,19 \%$ & 3 & $97,48 \%$ & 5 & $34,96 \%$ & 4 & $26,61 \%$ & 2 \\
\hline Garanti bank & $15,20 \%$ & 1 & $0,46 \%$ & 1 & $44,12 \%$ & 4 & $1,46 \%$ & 1 & $12,31 \%$ & 3 & $118,96 \%$ & 5 & $24,50 \%$ & 5 & $20,54 \%$ & 1 \\
\hline \begin{tabular}{|l|} 
Akbank \\
\end{tabular} & $15,16 \%$ & 1 & $0,12 \%$ & 1 & $37,87 \%$ & 3 & $1,54 \%$ & 1 & $12,58 \%$ & 3 & $127,99 \%$ & 5 & $31,14 \%$ & 5 & $24,23 \%$ & 1 \\
\hline Issbank & $16,00 \%$ & 1 & $0,35 \%$ & 1 & $50,63 \%$ & 5 & $1,42 \%$ & 1 & $11,54 \%$ & 3 & $124,05 \%$ & 5 & $27,46 \%$ & 5 & $21,23 \%$ & 1 \\
\hline Halkbank & $13,62 \%$ & 2 & $1,23 \%$ & 1 & $43,45 \%$ & 4 & $1,42 \%$ & 1 & $13,34 \%$ & 3 & $120,40 \%$ & 5 & $19,61 \%$ & 5 & $18,99 \%$ & 1 \\
\hline Șeker bank & $14,60 \%$ & 2 & $2,11 \%$ & 2 & $58,11 \%$ & 5 & $1,06 \%$ & 1 & $9,36 \%$ & 4 & $120,48 \%$ & 5 & $16,78 \%$ & 5 & $12,11 \%$ & 1 \\
\hline
\end{tabular}

\begin{tabular}{|c|c|c|c|c|c|c|c|c|c|c|c|c|c|c|c|c|}
\hline \multicolumn{17}{|c|}{2015} \\
\hline \multirow[b]{2}{*}{ Bank } & \multicolumn{2}{|c|}{\begin{tabular}{|l} 
Capital Adequacy \\
\end{tabular}} & \multicolumn{2}{|c|}{ Asset Quality Ratio } & \multicolumn{2}{|c|}{ Management Quality } & \multicolumn{4}{|c|}{ Earning Efficiency } & \multicolumn{4}{|c|}{ Liquidity } & \multicolumn{2}{|c|}{ Sensitivity to market risk } \\
\hline & CAR & Rating & $\mathrm{AQR}$ & Rating & $\mathrm{MQR}$ & Rating & EE1 & Rating & EE2 & Rating & L1 & Rating & L2 & Rating & Sens. & Rating \\
\hline Ziraatbank & $15,08 \%$ & 1 & $0,46 \%$ & 1 & $39,47 \%$ & 4 & $1,70 \%$ & 1 & $16,36 \%$ & 3 & $106,98 \%$ & 5 & $31,29 \%$ & 5 & $21,99 \%$ & 1 \\
\hline Garanti bank & $15,00 \%$ & 1 & $0,51 \%$ & 1 & $48,99 \%$ & 5 & $1,34 \%$ & 1 & $11,00 \%$ & 3 & $120,19 \%$ & 5 & $22,64 \%$ & 5 & $18,53 \%$ & 1 \\
\hline Akbank & $14,58 \%$ & 2 & $0,10 \%$ & 1 & $41,23 \%$ & 4 & $1,28 \%$ & 1 & $11,22 \%$ & 3 & $114,72 \%$ & 5 & $31,85 \%$ & 5 & $22,79 \%$ & 1 \\
\hline İşbank & $15,60 \%$ & 1 & $0,50 \%$ & 1 & $51,99 \%$ & 5 & $1,12 \%$ & 1 & $9,62 \%$ & 4 & $123,65 \%$ & 5 & $26,85 \%$ & 5 & $19,65 \%$ & 1 \\
\hline Halkbank & $13,83 \%$ & 2 & $0,73 \%$ & 1 & $45,63 \%$ & 4 & $1,23 \%$ & 1 & $11,92 \%$ & 3 & $120,72 \%$ & 5 & $19,73 \%$ & 5 & $16,55 \%$ & 1 \\
\hline Șeker bank & $13,66 \%$ & 2 & $2,69 \%$ & 3 & $62,28 \%$ & 5 & $0,42 \%$ & 3 & $4,06 \%$ & 5 & $128,80 \%$ & 5 & $18,81 \%$ & 5 & $12,83 \%$ & 1 \\
\hline
\end{tabular}

\begin{tabular}{|c|c|c|c|c|c|c|c|c|c|c|c|c|c|c|c|c|}
\hline \multirow[b]{3}{*}{ Bank } & \multicolumn{14}{|c|}{2016} & \multirow{2}{*}{\multicolumn{2}{|c|}{ Sensitivity to market risk }} \\
\hline & Capital & dequacy & Asset Qui & ity Ratio & Manage & at Quality & & Earning & Efficien & & & Liqui & & & & \\
\hline & CAR & Rating & $\mathrm{AQR}$ & Rating & $\mathrm{MQR}$ & Rating & EE1 & Rating & EE2 & Rating & L1 & Rating & L2 & Rating & Sens. & Rating \\
\hline Ziraatbank & $14,55 \%$ & 2 & $0,11 \%$ & 1 & $30,80 \%$ & 2 & $1,84 \%$ & 1 & $17,13 \%$ & 2 & $112,28 \%$ & 5 & $28,43 \%$ & 5 & $20,04 \%$ & 1 \\
\hline Garanti bank & $16,21 \%$ & 1 & $0,53 \%$ & 1 & $41,26 \%$ & 4 & $1,78 \%$ & 1 & $14,27 \%$ & 3 & $121,46 \%$ & 5 & $19,84 \%$ & 5 & $17,20 \%$ & 1 \\
\hline Akbank & $14,30 \%$ & 2 & $0,09 \%$ & 1 & $35,10 \%$ & 3 & $1,67 \%$ & 1 & $14,77 \%$ & 3 & $109,00 \%$ & 5 & $28,60 \%$ & 5 & $19,20 \%$ & 1 \\
\hline İşbank & $15,17 \%$ & 1 & $0,53 \%$ & 1 & $43,79 \%$ & 4 & $1,51 \%$ & 1 & $13,07 \%$ & 3 & $122,41 \%$ & 5 & $25,67 \%$ & 5 & $19,82 \%$ & 1 \\
\hline Halkbank & $13,08 \%$ & 2 & $0,72 \%$ & 1 & $41,45 \%$ & 4 & $1,11 \%$ & 1 & $12,00 \%$ & 3 & $128,30 \%$ & 5 & $20,16 \%$ & 5 & $15,87 \%$ & 1 \\
\hline Șeker bank & $13,11 \%$ & 2 & $3,12 \%$ & 3 & $57,03 \%$ & 5 & $0,53 \%$ & 3 & $4,94 \%$ & 5 & $119,05 \%$ & 5 & $12,47 \%$ & 5 & $11,09 \%$ & 1 \\
\hline
\end{tabular}


Table 22. Evaluation of Efficiency for a CAMELS Rating System

\begin{tabular}{|c|c|c|c|c|c|c|c|c|c|c|c|}
\hline \multicolumn{6}{|c|}{2005} & \multicolumn{6}{|c|}{2011} \\
\hline Bank & S\&P & Moody's & Fitch & JCR Eurasia & CAMELS Rate & Bank & S\&P & Moody's & Fitch & JCR Eurasia & CAMELS Rate \\
\hline Ziraatbank & BB- & $\mathrm{Bl}$ & $\mathrm{A}$ & - & 1,83 & Ziraatbank & - & Baа3 & $\mathrm{BB}+$ & BBB- & 2,55 \\
\hline Garanti bank & BB- & $\mathrm{Bl}$ & BB- & - & 2,73 & Garanti bank & $\mathrm{BB}$ & Baal & BBB- & - & 2,18 \\
\hline Akbank & - & $\mathrm{A} 3$ & $\mathrm{BB}+$ & - & 2,05 & Akbank & - & Baal & BBB- & - & 2,40 \\
\hline İşbank & BB- & $\mathrm{A} 3$ & $\mathrm{BB}$ & - & 2,30 & İşbank & $\mathrm{BB}$ & Baa2 & BBB- & - & 2,60 \\
\hline Halkbank & - & - & BB- & - & 2,50 & Halkbank & - & Baa3 & $\mathrm{BB}+$ & - & 2,20 \\
\hline Seker bank & - & - & B- & - & 2,78 & Seker bank & - & - & BB- & $\mathrm{BB}$ & 3,20 \\
\hline \multicolumn{6}{|c|}{2006} & \multicolumn{6}{|c|}{2012} \\
\hline Bank & S\&P & Moody's & Fitch & JCR Eurasia & CAMELS Rate & Bank & S\&P & Moody's & Fitch & JCR Eurasia & CAMELS Rate \\
\hline Ziraatbank & BB- & $\mathrm{Bl}$ & $\mathrm{A}$ & - & 1,95 & Ziraatbank & - & Baa2 & $\mathrm{BBB}$ & $\mathrm{BB}$ & 2,20 \\
\hline Garanti bank & BB- & $\mathrm{A} 3$ & $\mathrm{BB}+$ & - & 2,70 & Garanti bank & $\mathrm{BB}$ & Baa2 & BBB & $\mathrm{BBB}$ & 2,25 \\
\hline Akbank & - & $\mathrm{A} 3$ & $\mathrm{BB}+$ & - & 2,30 & Akbank & - & Baa2 & $\mathrm{BBB}$ & - & 2,05 \\
\hline İşbank & BB- & $\mathrm{A} 3$ & $\mathrm{BB}+$ & - & 2,35 & İşbank & $\mathrm{BB}$ & Baa2 & $\mathrm{BBB}$ & - & 2,40 \\
\hline Halkbank & - & - & BB- & - & 2,10 & Halkbank & - & Baa2 & $\mathrm{BBB}$ & $\mathrm{BB}$ & 1,98 \\
\hline Seker bank & - & - & B- & - & 2,55 & Seker bank & - & $\mathrm{Ba}$ & BB- & $\mathrm{BB}$ & 2,95 \\
\hline \multicolumn{6}{|c|}{2007} & \multicolumn{6}{|c|}{2013} \\
\hline Bank & S\&P & Moody's & Fitch & JCR Eurasia & CAMELS Rate & Bank & S\&P & Moody's & Fitch & JCR Eurasia & CAMELS Rate \\
\hline Ziraatbank & BB- & Baal & BB & - & 1,90 & Ziraatbank & - & Baa2 & BBB & BBB- & 2,23 \\
\hline Garanti bank & BB- & $\mathrm{A} 3$ & BBB- & - & 1,95 & Garanti bank & $\mathrm{BB}+$ & Baa2 & BBB & $\mathrm{BBB}+$ & 2,50 \\
\hline Akbank & - & $\mathrm{A} 3$ & BBB- & - & 2,13 & Akbank & - & Baa2 & BBB & - & 2,25 \\
\hline İşbank & BB- & $\mathrm{A} 3$ & BBB- & - & 2,10 & İşbank & $\mathrm{BB}+$ & Baa3 & $\mathrm{BBB}$ & - & 2,75 \\
\hline Halkbank & - & - & BB- & - & 2,05 & Halkbank & - & Baa2 & BBB & BBB- & 2,18 \\
\hline Seker bank & - & - & $\mathrm{B}$ & - & 2,55 & Şeker bank & - & $\mathrm{Bal}$ & BB- & BBB- & 2,95 \\
\hline \multicolumn{6}{|c|}{2008} & \multicolumn{6}{|c|}{2014} \\
\hline Bank & S\&P & Moody's & Fitch & JCR Eurasia & CAMELS Rate & Bank & S\&P & Moody's & Fitch & JCR Eurasia & CAMELS Rate \\
\hline Ziraatbank & BB- & Baal & $\mathrm{BB}$ & - & 2,10 & Ziraatbank & - & Baa3 & BBB & BBB- & 2,10 \\
\hline Garanti bank & BB- & $\mathrm{A} 3$ & BBB- & - & 2,58 & Garanti bank & $\mathrm{BB}+$ & Ваa3 & BBB- & $\mathrm{BBB}+$ & 2,30 \\
\hline Akbank & - & $\mathrm{A} 3$ & BBB- & - & 2,50 & Akbank & - & Baa3 & BBB- & - & 2,05 \\
\hline İşbank & BB- & $\mathrm{A} 3$ & BBB- & - & 2,25 & İşbank & $\mathrm{BB}+$ & Baa3 & BBB- & - & 2,55 \\
\hline Halkbank & - & - & $\mathrm{BB}$ & - & 2,25 & Halkbank & - & Baa3 & $\mathrm{BBB}$ & BBB- & 2,50 \\
\hline Seker bank & - & - & $\mathrm{B}$ & - & 3,05 & Seker bank & - & $\mathrm{A} 3$ & BB- & BBB- & 3,03 \\
\hline \multicolumn{6}{|c|}{2009} & \multicolumn{6}{|c|}{2015} \\
\hline Bank & S\&P & Moody's & Fitch & JCR Eurasia & CAMELS Rate & Bank & S\&P & Moody's & Fitch & JCR Eurasia & CAMELS Rate \\
\hline Ziraatbank & - & Baa3 & $\mathrm{BB}+$ & BBB- & 1,80 & Ziraatbank & - & Ваa3 & BBB & BBB- & 2,30 \\
\hline Garanti bank & BB- & Baal & BBB- & - & 2,00 & Garanti bank & $\mathrm{BB}+$ & Baa3 & BBB & $\mathrm{BBB}+$ & 2,55 \\
\hline Akbank & - & Baal & BBB- & - & 2,23 & Akbank & - & Baа3 & BBB- & - & 2,50 \\
\hline İşbank & $\mathrm{BB}$ & Baa2 & BBB- & - & 2,13 & İşbank & $\mathrm{BB}+$ & Baa3 & BBB- & - & 2,63 \\
\hline Halkbank & - & Baa3 & $\mathrm{BB}+$ & - & 1,85 & Halkbank & - & Baa3 & BBB & BBB- & 2,50 \\
\hline Seker bank & - & - & $\mathrm{B}$ & - & 2,90 & Şeker bank & - & $\mathrm{A} 3$ & BB- & BBB- & 3,45 \\
\hline \multicolumn{6}{|c|}{2010} & \multicolumn{6}{|c|}{2016} \\
\hline Bank & S\&P & Moody's & Fitch & JCR Eurasia & CAMELS Rate & Bank & S\&P & Moody's & Fitch & JCR Eurasia & CAMELS Rate \\
\hline Ziraatbank & - & Baa3 & $\mathrm{BB}+$ & BBB- & 2,05 & Ziraatbank & - & $\mathrm{Bal}$ & BBB- & BBB- & 1,93 \\
\hline Garanti bank & BB & Baal & BBB- & - & 2,33 & Garanti bank & $\mathrm{BB}$ & $\mathrm{Bal}$ & BBB & $\mathrm{BBB}+$ & 2,30 \\
\hline Akbank & - & Baal & BBB- & - & 2,35 & Akbank & - & Bal & $\mathrm{BB}+$ & - & 2,25 \\
\hline İşbank & $\mathrm{BB}$ & Baa2 & BBB- & - & 2,43 & İşbank & $\mathrm{BB}$ & $\mathrm{Bal}$ & $\mathrm{BB}+$ & - & 2,30 \\
\hline Halkbank & - & Baa3 & $\mathrm{BB}+$ & - & 2,00 & Halkbank & - & $\mathrm{Bal}$ & $\mathrm{BBB}$ & BBB- & 2,50 \\
\hline Şeker bank & - & - & $\mathrm{B}+$ & - & 3,05 & Şeker bank & - & Baа2 & BB- & BBB & 3,45 \\
\hline
\end{tabular}

\section{CONCLUSIONS}

This study analyzes the performance and financial credibility of six Turkish banks for period 2005-2016. The sample comprises two state-owned deposit banks, three private-owned deposit banks, and one foreign bank. As one of the most popular methods for measuring banking performance, CAMELS method is used to analyze the performance of the banks. In this study, 27 ratios under 6 categories, namely Capital 
Adequacy, Asset Quality, Management Efficiency, Earning Quality, Liquidity, Sensitivity, have been used to measure the CAMELS ratings of banks. Every specific ratio has been multiplied by its own weight and as a result, all the related weighted ratios have been summed up to give one number for each category. After all of the calculations, there are 6 numbers for 6 categories. These 6 numbers have been multiplied by their own assigned weights of the related category which finally results in a number for each year as the CAMELS rate. This number has been computed for 12 years (2005-2016) for each bank in the study.

First, the banks have been compared with respect to their performance in 2016. This analysis illustrated that banks have negligible difference in terms of their performance rating for that specific year. In other words, all of them remain within a narrow range. It means that the chosen banks have similar financial structure and have tried to keep themselves within the boundaries of prudential rules and standards defined by BRSA. Besides it also indicates that supervision of BRSA has proved satisfactorily efficient and effective. Then for all the banks in the sample, CAMELS components have been ranked based on the average rate for the last three years of the sample period, namely 2014, 2015 and 2016. This analysis, however, showed that Ziraat Bank stood at the top position followed by Garanti Bank and Akbank. Halkbank ranked as the last bank in this comparison. To compare the ratings two ANOVA tests have been performed. These ANOVA tests are quite different from each other in terms of data used. In the first ANOVA test, the data is the average ranks for the $\mathrm{C}, \mathrm{A}, \mathrm{M}, \mathrm{E}, \mathrm{L}$ and $\mathrm{S}$ values over the last three years. However, the second ANOVA test uses overall CAMELS ratios (not the ranks) for six banks for the twelve years analyzed (20052016). This is the first study, to our knowledge, to be able to make such an ANOVA analysis, since we have the sufficient number of years to be analyzed. ANOVA results state that there is a statistically significant difference between the means of CAMELS ratios. Finally, in the last part of the study, CAMELS rating results have been compared to International Rating Agencies' ratings. This comparison has shown that the ratings of institutions do lag the financial indicators of the companies and even can be not reflective of the current financial condition of the company. But the trend of the ratings and rankings of financial indicators are consistent over a long period of time.

The study shows that CAMELS analysis is a better way of measuring a bank's performance. It can capture the changes in the performance of a bank immediately they occur. With CAMELS analysis, it is also quite easy to understand the reason of deficiencies by carefully inspecting the ratios behind the CAMELS ratio. Thus, the main recommendation of the study would be to use CAMELS analysis to understand what precautions should be taken before the deficiencies in the performance affect the rating done by agencies. That should be of course a continuous process for a bank manager. 


\section{REFERENCES}

Öztorul, G. (2011). Performance Evaluation of Banks And Banking Groups: Turkey Case. Master Thesis, Middle East Technical University, Department of Economics, İstanbul.

Akbank Website. (n.d.). Retrieved from http://www.akbank.com/en-us/investorrelations/Pages/Financials.aspx

Arıçlik, G. (2010). Ticari Bankalarda Performans Ölçümü: CAMELS Analizine Dayalı Bir I. Yüksek Lisans Tezi, Dokuz Eylül Üniversitesi, Sosyal Bilimler Enstitüsü, İzmir.

Babar, H. Z., \& Lions, C. (2011). CAMELS Rating System for Banking Industry in Pakistan, Does CAMELS system provide similar rating as PACRA system in assessing the performance of banks in Pakistan? Umea University, Umea School of Business. Umea School of Business.

Banking Regulation and Supervision Agency - BDDK. (n.d.). Retrieved from https://www.bddk.org.tr/WebSitesi/English.aspx

Barr, R. S., Killgo, K. A., Siems, T. F., \& Zimmel, S. (2002). "Evaluating the productive efficiency and performance of US commercial banks". Managerial Finance, 28 (8), 3-25.

Broz, L. (1997). The International Origins of the Federal Reserve System. Cornell University Press.

Christopoulos, A., Mylonakis, J., \& Diktapanidis, P. (2011). Could Lehman Brothers' Collapse Be Anticipated? An Examination Using CAMELS Rating System. International Business Research, 4 (2).

Cole, R. A., \& Gunther, J. W. (1995). A CAMEL Rating's Shelf Life. Federal Reserve Bank of Dallas Financial Industry Studies, 13-20.

Cox, D., \& Cox, M. (2006). The Mathematics of Banking and Finance. John Wiley \& Sons Ltd.

Dang, U. (2011). The CAMEL Rating System in Banking Supervision (A Case Study). Arcada University of Applied Sciences. International Business.

Dash, M., \& Das, A. (2009). A CAMELS Analysis of the Indian Banking Industry. Social Science Research.

Dincer, H., Gencer, G., Orhan, N., \& Sahinbas, K. (2011). A Performance Evaluation of the Turkish Banking Sector after the Global Crisis via CAMELS Ratios. Procedia Social and Behavioral Sciences, 1530-1545.

Economist Intelligence Unit. (2016, February 17). Retrieved from Economist Intelligence Unit: http://www.eiu.com/industry/article/603951444/downturncatches-up-with-turkeys-banks/2016-02-17

FitchRatings. (n.d.). https://www.fitchratings.com/site/home. Retrieved from https://www.fitchratings.com/site/home

Garanti Bank Website. (n.d.). Retrieved from https://www.garanti.com.tr/en/our_company/investor_relations.page 
Grier, W. A. (2007). Credit Analysis of Financial Institutions (2nd ed.). Euromoney Institutional Investor PLC.

$\begin{array}{llll}\text { Halkbank } & \text { (n.d.). } & \text { Rebsite. } & \text { from }\end{array}$ https://www.halkbank.com.tr/en/international-banking/83/financialreports?AspxAutoDetectCookieSupport=1

İşbank Website. (n.d.). Retrieved from https://www.isbank.com.tr/EN/aboutisbank/investor-relations/publications-and-results/financialstatements/Pages/financial-statements.aspx

Ishaq, A., Karim, A., Ahmed, S., \& Zaheer, A. (2016). Evaluating Performance of Commercial Banks in Pakistan: "An Application of Camel Model". Journal of Business \& Financial Affairs, 5 (1).

JCR Eurasia Rating. (n.d.). http://www.jcrer.com.tr/. Retrieved from http://www.jcrer.com.tr/

Masood, O., Ghauri, S., \& Aktan, B. (2016). Predicting Islamic Banks Performance Through CAMELS Rating Model. Banks and Bank Systems .

Mishra, S. K., \& Aspal, P. K. (2013). A CAMEL Model Analysis of State Bank Group. World Journal of Social Sciences , 3, 36- 55.

Moody's. (n.d.). https://www.moodys.com/. Retrieved from Moody's: https://www.moodys.com/

Nonperforming Loan - NPL. (n.d.). Retrieved from Investopedia: https://www.investopedia.com/terms/n/nonperformingloan.asp

Rozzani, N., \& Rahman, R. (2013). "Camels and Performance Evaluation of Banks in Malaysia: Conventional Versus Islamic". Journal of Islamic Finance and Business Research, 2 (1), 36-45.

S\&P Global. (n.d.). https://www.standardandpoors.com/en_US/web/guest/home. Retrieved from https://www.standardandpoors.com/en_US/web/guest/home

Siems, T. F., \& Barr, R. S. (1998). "Benchmarking the Productive Efficiency of U.S.

Banks: Financial Industry Studies". Federal Reserve Bank of Dallas.

$\begin{array}{llll}\text { Şekerbank } & \text { Website. } & \text { (n.d.). } & \text { Retrieved }\end{array}$ http://www.sekerbank.com/en/investorrelations/statements

Şen, A., \& Solak, S. (2011). Ticari bankacılık sektörünün CAMELS analizi: Türkiye örneği. Finans Politik ve Ekonomik Yorumlar Dergisi , 48 (554).

The Banks Association of Turkey. (n.d.). Retrieved from https://www.tbb.org.tr/tr

Yuksel, S., Dincer, H., \& Hacioglu, U. (2015). CAMELS-based Determinants for the Credit Rating of Turkish Deposit Banks. International Journal of Finance \& Banking Studies, 4 (4).

Ziraat Bank Website. (n.d.). Retrieved from https://www.ziraatbank.com.tr/en/InvestorRelations/Financials/Pages/AuditReport AndFinancialStatements.aspx 